\title{
Depth-specific distribution of Bacteroidetes in the oligotrophic Eastern Mediterranean Sea
}

\author{
Martina Blümel, Jörg Süling, Johannes F. Imhoff* \\ Leibniz-Institut für Meereswissenschaften an der Universität Kiel, Düsternbrooker Weg 20, 24105 Kiel, Germany
}

\begin{abstract}
Representatives of the phylum Bacteroidetes are repeatedly reported to be abundant members of oceanic bacterioplankton, probably because of their ability to degrade complex organic matter. 16S rDNA analysis was performed in order to address the importance of this phylum in a highly oligotrophic region such as the Eastern Mediterranean Sea and to investigate its distribution patterns and community composition. A new antisense primer was designed for PCR and used in combination with the general eubacterial sense primer $27 \mathrm{~F}$ to specifically target Bacteroidetes representatives. Data were correlated with water depth and water mass properties. Denaturant gradient gel electrophoresis (DGGE) analysis and sequencing of environmental clone libraries revealed specific distribution patterns. A major fraction of the sequences was assigned to the AGG58 cluster, a branch of yet uncultured members of the Bacteroidetes lineage. Our results demonstrate a considerable diversity within the Bacteroidetes lineage in the oligotrophic Eastern Mediterranean Sea. Differing water mass properties are considered to be of major relevance for the spatial distribution with depth; several environmental clone sequence clusters could be specifically assigned to a defined water mass or to the deep waters of investigated locations. Depth-specific distribution of Bacteroidetes is demonstrated for the first time by the results of this study.
\end{abstract}

KEY WORDS: Bacteroidetes $\cdot$ Depth specific distribution $\cdot$ Eastern Mediterranean Sea $\cdot$ Bacterial diversity

\section{INTRODUCTION}

The phylum Bacteroidetes is a widely distributed group of chemoheterotrophic bacteria in marine habitats and is abundant within marine bacterioplankton (Bowman et al. 1997, Glöckner et al. 1999, Cottrell \& Kirchman 2000, Fry 2000, Kirchman 2002). It is a major eubacterial group and can be divided into different lineages based on 16S ribosomal DNA sequences. Major branches are the Cytophaga-Flavobacterium lineage, the Bacteroides lineage as well as the families Sphingobacteriaceae, Flexibacteraceae and Crenotrichaceae (Kirchman 2002). A new family within the phylum, the Cryomorphaceae, has recently been proposed (Bowman et al. 2003), phylogenetically branching between the families Flavobacteriaceae and Bacteroidaceae. The type genus of this new family is the genus Cryomorpha, type species C. ignava, originally isolated from marine and marine-derived habitats in Antarctica (Bowman et al. 2003).

Representatives of Bacteroidetes were found to comprise $14 \%$ of bacterial isolates from a marine habitat (Uphoff et al. 2001), but the majority of Bacteroidetes sequences detected in environmental samples by molecular methods remains as yet uncultured (DeLong et al. 1993, Suzuki et al. 1997, Eilers et al. 2000).

Members of the Bacteroidetes represented 10 to $40 \%$ of total bacterial numbers (DAPI counts) in ocean waters (Glöckner et al. 1999, Abell \& Bowman 2005a) as observed by fluorescence in situ hybridisation (FISH). In lakes, a growth rate 2 -fold faster than that of other bacterial groups was observed for the Cytophaga-Flavobacterium lineage (Jürgens et al. 1999), providing a possible explanation for the high abundances of this group in aquatic systems. 
In contrast to the data obtained by FISH, only few Bacteroidetes sequences have been found in clone libraries from open-ocean environments using general eubacterial primers (5 to $20 \%$; Kirchman 2002, Kirchman et al. 2003). Bacteroidetes sequences are often underrepresented in clone libraries and consequently in DNA sequence databases (O'Sullivan et al. 2004), because general eubacterial primers are likely to discriminate against this phylum (Suzuki et al. 2001).

Although data from FISH suggest that this phylum represents an important part of bacterial communities in ocean waters, little is known of its ecological function and specific distribution (Reichenbach 1991, Hagström 2000, Hagström et al. 2000, Kirchman 2002). Representatives of the Bacteroidetes and especially the Flavobacterium lineage are known to be degraders of complex organic matter. In recent years, the distribution of marine representatives of Bacteroidetes has attracted increasing attention, mainly due to their supposed essential role in vertical energy and carbon flow (Kirchman 2002, Bowman et al. 2003). Abell \& Bowman (2005a) hypothesized an opportunistic response of Flavobacteria to the organic carbon present. As major decomposers, uptake and degradation (especially of high molecular weight, HMW) of organic matter is assumed for this bacterial group (Cottrell \& Kirchman 2000, Kirchman 2002). Pinhassi et al. (2004) further emphasized the particular importance of Bacteroidetes in the processing of organic matter during algal blooms.

Crump et al. (1999) detected a high proportion of Bacteroidetes in the particle-attached fraction of an estuarine system, underlining the importance of this bacterial phylum especially in the degradation of marine snow aggregates. DeLong et al. (1993) found that particle-attached bacterial assemblages shared no identical rRNA types with free-living assemblages and suggested major compositional differences between the 2 assemblages. DeLong et al. (1993) also retrieved the first sequence of the so-called 'AGG58' cluster of the Bacteroidetes (O'Sullivan et al. 2004) from marine snow in the Santa Barbara Channel, USA. The AGG58 cluster is a coherent branch with closest similarity to the Flavobacteria lineage, now incorporated into the new family Cryomorphaceae (O'Sullivan et al. 2004, Abell \& Bowman 2005b). The AGG58 cluster comprises sequences from such various environments as the Santa Barbara Channel (DeLong et al. 1993), the Delaware Estuary (Kirchman et al. 2003), the Arctic Ocean (Bano \& Hollibaugh 2002) and coastal seawater off North Carolina (Rappé et al. 1997). It is therefore considered to be cosmopolitan (O'Sullivan et al. 2004). The different branches of the cluster showed changes in dominance during the course of a phytoplankton bloom, leading to the assumption that different members of the cluster are specialized to different ecologi- cal conditions (O'Sullivan et al. 2004). O'Sullivan et al. (2004) found comparably low similarity values of Bacteroidetes clones to GenBank sequences and concluded that the phylogenetic diversity of this group is not as well investigated as that for the proteobacteria.

A specific prokaryotic community is considered to inhabit the deep Mediterranean Sea (Zaballos et al. 2006). Zaballos et al. (2006) found substantial differences in the bacterial community composition compared to other ocean environments. In general, the ubiquitous alpha-bacterial SAR-11 cluster contributed a major fraction of the total bacterial community of open ocean environments, whereas in the Ionian Basin (Eastern Mediterranean Sea), Gammaproteobacteria dominated the bacterioplankton assemblage (Zaballos et al. 2006). Bacteroidetes were the most heterogenous group retrieved in clone libraries of seawater samples from the Greenland Sea and the Ionian Sea, indicating a high diversity within this group in these waters.

To date, depth-specific distribution has been reported for several bacterial phyla, e.g. the green non-sulfur bacteria (Gordon \& Giovannoni 1996), the ubiquitous SAR11 cluster (Field et al. 1997) and Deltaproteobacteria (Wright et al. 1997). Lee \& Fuhrman (1991) reported a varying bacterial community composition with depth, but the phylum Bacteroidetes has never been the focus of studies dealing with depth-specific distribution. However, with changing availability of HMW organic matter with depth, a depth-specific distribution particularly of Bacteroidetes representatives as major degraders seems likely. Seritti et al. (2003) reported a water-mass-specific distribution of dissolved organic carbon (DOC) in the Eastern Mediterranean Sea. Bacteroidetes as major mineralizers of particulate organic carbon (POC) may contribute a major fraction of DOC, further indicating a possible depth- or even water-mass-specific distribution of this phylum.

The Mediterranean Sea can be primarily characterized by unusually high deep water temperatures $\left(>13^{\circ} \mathrm{C}, \mathrm{CIESM} 2003\right)$ and extremely low nutrient concentrations (Krom et al. 1991). The Eastern Mediterranean is divided into 2 main sub-basins, the Levantine Basin and the Ionian Basin (Theocharis et al. 1993). Characteristic surface water masses of the Eastern Mediterranean Sea are the Levantine Surface Water (LSW, origin: Levantine Basin) and the Modified Atlantic Water (MAW, origin: Atlantic Ocean). Intermediate water masses are the Levantine Intermediate Water (LIW, main origin: Rhodes cyclonic gyre; Theocharis et al. 1999) and the newly formed Cretan Intermediate Water (CIW, origin: Aegean Sea; Schlitzer et al. 1991, Manca et al. 2003). Deep water circulation has changed over the last decade: the Adriatic Sea as primary source of Eastern Mediterranean Deep Water (EMDW $_{\text {Adri }}$ Kress et al. 2003) has been replaced by the 
Aegean Sea (Roether et al. 1996, Lascaratos et al. 1999, water mass designation $\mathrm{EMDW}_{\text {Aegi }}$ Kress et al. 2003). This phenomenon was termed the Eastern Mediterranean Transient (EMT).

Well-defined water mass properties, distinguished by different physical properties (e.g. temperature, salinity), offer the possibility to analyze the variation of microbial communities within the different water masses. Because of the special importance of Bacteroidetes in marine systems, the present study focused on this lineage by using a combined molecular approach of DGGE and 16S rDNA clone libraries. Community variations of this important bacterial phylum were investigated as a function of water mass and depth.

\section{MATERIALS AND METHODS}

Samples were collected in the Eastern Mediterranean Sea during the RV 'Meteor' Cruise 44, Leg 4 in April and May 1999. Samples from 7 stations (Stn 219: SW-Cyprus, Levantine Basin; Stn 236: Levantine Basin; Stns 254, 265: M40/3D-Ierapetra Basin, Cretan Passage; Stn 291: Cretan Passage; Stns 293, 295 : Ionian Basin) were analyzed by DGGE. The M40/3D sample was collected 1 yr earlier in January 1998. Fig. 1 shows the geographical locations of the stations. At each station at least 12 different depths covering different water masses were sampled by a rosette sampler (24 Niskin bottles) attached to a CTD probe. For collection of bacterial community DNA, 51 of water were filtered through polycarbonate filters (Millipore) with $0.2 \mu \mathrm{m}$ pore size. Filters were stored at $-20^{\circ} \mathrm{C}$ until use. Stns 219, 254 and 295 were selected for comparison of different examples of water mass distribution.
Characteristic physical properties (e.g. temperature and salinity) of the water masses at these stations are shown in Table 1. Total numbers of prokaryotes were determined using the acridine orange direct count method and a Zeiss axioplan epifluorescence microscope.

Filters used for DNA extraction were treated with lysozyme solution (20 $\mathrm{mg} \mathrm{ml}^{-1}$ lysozyme; $20 \mathrm{mM}$ Tris$\mathrm{HCl}, \mathrm{pH} 8.0 ; 2$ mM EDTA; $1.2 \%$ Triton) and incubated at $37^{\circ} \mathrm{C}$ for at least $30 \mathrm{~min}$. DNA extraction was performed using a QIAamp DNA mini kit (Qiagen) following the manufacturer's instructions.

PCR for 16S rDNA cloning and for DGGE analysis was performed with 'ready-to-go' PCR beads (Amersham Pharmacia Biotech) in a Techne Progene thermocycler. A new PCR antisense primer, Cyt1020R: CATTTAAGCCTTGGTAAGG, Escherichia coli Positions 978 to 995, Flavobacterium aquatile Positions 964 to 982, was designed for the specific amplification of Bacteroidetes sequences. This primer was used in combination with the general eubacterial primer 27F (Brosius et al. 1978). The performance of the new primer for amplification of Bacteroidetes sequences is evaluated in the 'Results'. PCR was performed using the following protocol: an initial denaturation step $\left(94^{\circ} \mathrm{C}\right.$ for 2 min) followed by 15 touchdown cycles with denaturation at $94^{\circ} \mathrm{C}$ for $30 \mathrm{~s}$, a decreasing annealing temperature from 65 to $50^{\circ} \mathrm{C}$ and elongation at $72^{\circ} \mathrm{C}$ for $40 \mathrm{~s}$. Touchdown cycles were followed by 20 cycles at $94^{\circ} \mathrm{C}$ (denaturation $30 \mathrm{~s}$ ), $50^{\circ} \mathrm{C}$ annealing for $30 \mathrm{~s}$ and elongation at $72^{\circ} \mathrm{C}$ for $40 \mathrm{~s}$. Final annealing was performed at $42^{\circ} \mathrm{C}$ for $60 \mathrm{~s}$ and final elongation at $72^{\circ} \mathrm{C}$ for $5 \mathrm{~min}$.

Specific amplification of Bacteroidetes sequences for DGGE was assured by using a nested PCR protocol. The first amplification was performed with the newly

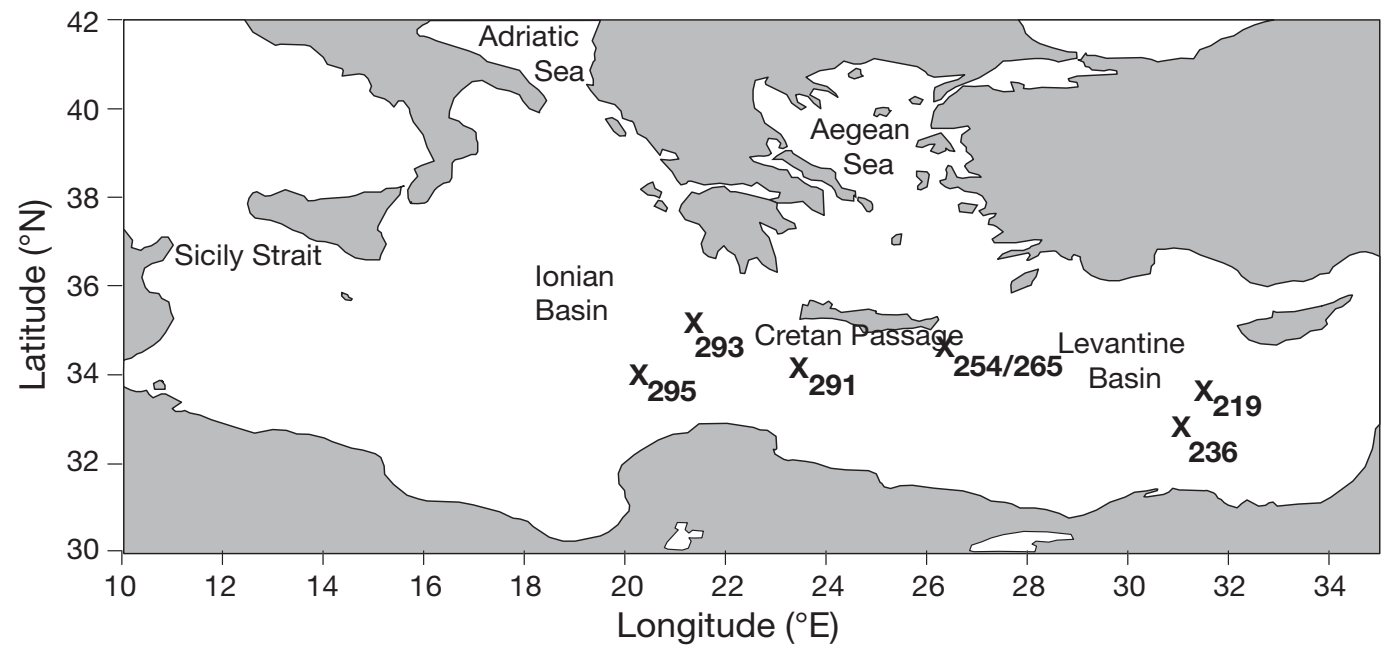

Fig. 1. Locations of stations for cloning experiments and DGGE: Stn 219, SW-Cyprus (Levantine Basin, 3407'96"N,

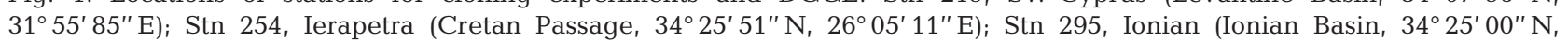
$20^{\circ} 20^{\prime} 15^{\prime \prime} \mathrm{E}$ ); Additional DGGE experiments (data not presented) were made at Stns 236 (Levantine Basin), 265 (Cretan Passage), 291, 293 (Ionian Basin) 
Table 1. Temperature $(T)$, Salinity $(S)$, geographic locations and sampling depths of main stations. Samples used for clone library construction are underlined. LSW: Levantine Surface Water; LIW: Levantine Intermediate Water; CIW: Cretan Intermediate Water; EMDW: Eastern Mediterranean Deep Water $($ Adr $=$ Adriatic, Aeg $=$ Aegean Sea $) ;$ MAW: Modified Atlantic Water

\begin{tabular}{|c|c|c|c|}
\hline Depth (m) & $S(\mathrm{psu})$ & $T\left({ }^{\circ} \mathrm{C}\right)$ & Water mass \\
\hline \multicolumn{4}{|c|}{ Stn 219 (SW-Cyprus, Levantine Basin) } \\
\hline 10 & 38.9185 & 17.4885 & LSW \\
\hline 100 & 38.9317 & 16.9976 & LSW \\
\hline 200 & 38.9322 & 16.4295 & LSW \\
\hline 250 & 39.0276 & 15.9164 & LIW \\
\hline$\underline{300}$ & $\underline{39.0193}$ & 15.2973 & $\underline{\text { LIW }}$ \\
\hline$\overline{500}$ & $\overline{38.8401}$ & $\overline{14.0528}$ & LIW/CIW \\
\hline 750 & 38.7761 & 13.8060 & CIW \\
\hline 1000 & 38.7456 & 13.7198 & CIW/ EMDW \\
\hline 1300 & 38.7326 & 13.7129 & EMDW $_{\text {Aeg }}$ \\
\hline 2000 & 38.7822 & 13.9345 & EMDW $_{\text {Aeg }}$ \\
\hline$\underline{2300}$ & $\underline{38.8082}$ & $\underline{14.0503}$ & $\underline{E M D W}_{\text {Aeg }}$ \\
\hline 2500 & 38.8197 & 14.1143 & EMDW $_{\text {Aeg }}$ \\
\hline \multicolumn{4}{|c|}{ Stn 254 (Ierapetra; Cretan Passage) } \\
\hline 10 & 38.5366 & 17.2863 & MAW \\
\hline 50 & 38.5941 & 16.5287 & MAW \\
\hline 100 & 38.7563 & 16.0934 & LIW \\
\hline 200 & 39.0226 & 15.2898 & MAW \\
\hline 500 & 38.8122 & 13.9362 & LIW \\
\hline 1000 & 38.7567 & 13.7573 & CIW \\
\hline 1500 & 38.7811 & 13.8821 & $\mathrm{EMDW}_{\mathrm{Adr}}$ \\
\hline$\underline{2000}$ & $\underline{38.8222}$ & $\underline{14.0646}$ & $\underline{E M D W}_{\text {Aeg }}$ \\
\hline 2500 & 38.8404 & 14.1757 & $\mathrm{EMDW}_{\mathrm{Aeg}}$ \\
\hline 3000 & 38.8407 & 14.2481 & EMDW $_{\text {Aeg }}$ \\
\hline 4000 & 38.8718 & 14.5007 & EMDW $_{\text {Aeg }}$ \\
\hline 4250 & 38.8739 & 14.5541 & $\mathrm{EMDW}_{\text {Aeg }}$ \\
\hline \multicolumn{4}{|c|}{ Stn 295 (Ionian Basin) } \\
\hline 10 & 38.4052 & 17.8304 & MAW \\
\hline 30 & 38.5154 & 16.2233 & MAW \\
\hline 50 & 38.5828 & 15.6473 & MAW \\
\hline 100 & 38.5998 & 14.6357 & MAW/LIW \\
\hline 200 & 38.8654 & 14.3537 & LIW \\
\hline 300 & 38.8465 & 14.1192 & LIW \\
\hline 400 & 38.8039 & 13.9166 & LIW \\
\hline 500 & 38.7779 & 13.8046 & LIW \\
\hline 900 & 38.7429 & 13.6954 & CIW \\
\hline 1500 & 38.7313 & 13.7099 & $\mathrm{EMDW}_{\mathrm{Adr}}$ \\
\hline 2000 & 38.7116 & 13.7022 & $\mathrm{EMDW}_{\mathrm{Adr}}$ \\
\hline 2500 & 38.6920 & 13.7071 & $\mathrm{EMDW}_{\mathrm{Adr}}$ \\
\hline 2650 & 38.6918 & 13.7277 & $\mathrm{EMDW}_{\mathrm{Adr}}$ \\
\hline 2700 & 38.6943 & 13.7439 & $\mathrm{EMDW}_{\mathrm{Adr}}$ \\
\hline
\end{tabular}

designed antisense primer Cyt1020R in combination with 27F. In the second PCR for DGGE, Primers 342GC-F and 534R (Muyzer et al. 1993) were used. PCR conditions for both reactions were selected as described above.

A general eubacterial amplification and control 16S rDNA clone library was created using Primers $27 \mathrm{~F}$ and 1387R (Marchesi et al. 1998). PCR conditions were selected as described above for the amplification of Bacteroidetes sequences in order to check the specificity of the new antisense primer Cyt-1020-R.
DGGE was performed with a CBS Scientific DGGE2001 system. DGGE gels contained a denaturing gradient from 40 to $64 \%$ (100\% defined as $7 \mathrm{M}$ urea and $10 \mathrm{M}$ formamide according to Abrams \& Stanton 1992) and an acrylamide $(37.5: 1 \mathrm{v} / \mathrm{v})$ gradient from 6 to $8 \%$ (Petri \& Imhoff 2001). Electrophoresis was run for $14 \mathrm{~h}$ at $80 \mathrm{~V}$.

For sequencing of DGGE bands, selected DGGE bands were excised and reamplified. Reamplification of the excised fragments was performed using a primer specifically designed to bind within the GC-clamp (GC-Clamp-M F: GGGGGCACGGGGGGC; Younis 2001). Thus, exclusive amplification of the excised fragment could be assured. For reamplification, the primer GC/M was combined with Primer 534R with the following PCR conditions: $50^{\circ} \mathrm{C}$ annealing temperature for $40 \mathrm{~s}$, elongation at $72^{\circ} \mathrm{C}$ for $40 \mathrm{~s}$ and denaturation at $94^{\circ} \mathrm{C}$ for $30 \mathrm{~s}$ for 25 cycles. Cluster analysis of DGGE gel band patterns and ANOSIM was performed using PAST software (Hammer et al. 2001, available at: http:// palaeo-electronica.org/2001-1/past/issue1-01.htm).

For cloning experiments, DNA was purified with the QIAquick PCR purification kit (Qiagen) following the manufacturer's instructions. Cloning was realized with the TOPO TA cloning kit for Sequencing (Invitrogen). For screening, 50 colonies per depth were chosen randomly. Screening PCR after cloning experiments was performed with Primers M13F and M13R (Yanisch-Peron et al. 1985) using $55^{\circ} \mathrm{C}$ annealing temperature for $30 \mathrm{~s}, 72^{\circ} \mathrm{C}$ elongation for $90 \mathrm{~s}$ and $94^{\circ} \mathrm{C}$ denaturation for $30 \mathrm{~s}$ for 25 cycles. Fragments with correct insert length (1000 nucleotides, nt) were chosen for sequencing.

The 'big dye terminator cycle sequencing ready reaction kit' (Applied Biosystems) was used for cycle sequencing following the manufacturer's instructions. Primer 534R was applied for cycle sequencing. Afterwards, DNA was purified using a 2-step ethanol precipitation protocol; $80 \mu \mathrm{l}$ of $80 \%$ ethanol (Merck) were applied to each reaction in the first step. After $30 \mathrm{~min}$ precipitation time the reaction was centrifuged for $20 \mathrm{~min}$ at $4^{\circ} \mathrm{C}$ and $13500 \mathrm{rpm}(16300 \times \mathrm{g})$ (Rotor No. 12454) in a Sigma $3 k 30$ centrifuge. Supernatant was removed and $250 \mu \mathrm{l}$ of $70 \%$ ethanol were added, followed by an additional centrifugation step for $10 \mathrm{~min}$ at $4^{\circ} \mathrm{C}$ and $13500 \mathrm{rpm}(16300 \times g)$. Supernatant was removed again, remaining ethanol was evaporated and $20 \mu \mathrm{l}$ template suppression reagent (Applied Biosystems) were added. For sequence analysis an ABI 310 genetic analyzer (Perkin Elmer Applied Biosystems) was used. Sequences obtained from DGGE bands comprised 140 to $190 \mathrm{nt}$, sequences derived from cloning experiments comprised 200 to $500 \mathrm{nt}$. The entire insert length of several DNA fragments was sequenced (approx. $1000 \mathrm{nt}$ ). Sequences were edited 
by Chromas (Version 1.45) and compared with the NCBI database using BLAST (Altschul et al. 1997; see also www.ncbi.nlm.nih.gov/blast/Blast.cgi?CMD=Web\& LAYOUT=TwoWindows $\& A U T O \_F O R M A T=S e m i a u t o \&$ PAGE=Nucleotides\&NCBI_GI=yes\&FILTER=L\&HITLIST SIZE=100\&SHOW_OVERVIEW=yes\&AUTO_FORMAT = yes\&SHOW_LINKOUT=yes) to obtain first estimates on closest phylogenetic relatives.

All sequences were aligned to the ARB database (see http://www.arb-home.de) (Ludwig et al. 2004) using the integrated aligner function. The 8 closest phylogenetic relatives according to BLAST were added to the ARB database when not already present. Alignments were refined manually and aligned sequences were added to the ARB tree (quick add marked function, parsimony). Based on the affiliation to the ARB backbone tree, 63 environmental clone sequences were selected for further phylogenetic calculations with PHYML (Guindon \& Gascuel 2003). Maximum likelihood analysis was performed assuming nucleotide substitution according to the general time reversible (GTR) model. For primer design, a type-strain alignment of major Bacteroidetes representatives was calculated using default parameters of the ClustalX program (Thompson et al. 1994).

16S rDNA sequences determined during this study were deposited in the EMBL Nucleotide Sequence Database and were assigned Accession Nos. AM411213AM411295, AM411296-AM411358, AM411613, AM398930-AM398941, AJ577829, AJ635360-AJ635362.

Rarefaction analysis of Bacteroidetes-specific cloning experiments was performed using the freeware program aRarefactWin (Holland 2003, available at University of Georgia Stratigraphy Laboratory, www.uga. edu/strata/software/) and regression analysis was made using SigmaPlot Version 6.00 (SPSS).

\section{RESULTS}

The stations investigated displayed different hydrographical conditions with regard to water mass distribution, especially in respect to the contribution of different water masses to the deep water (Fig. 2). At Stn 219 (Levantine Basin), there was only slight EMDW $\mathrm{Edr}_{\mathrm{A}}$ contribution to the deep water. At Stn 254 (Ierapetra Basin), EMDW $\mathrm{Edr}_{\text {ad }}$ was underlain by $\mathrm{EMDW}_{\text {Aeg }}$ below 1500 m. At Stn 295 (Ionian Basin), deep water was exclusively provided by EMDW $\mathrm{Adr}_{\mathrm{A}}$. With regard to surface waters, at Stn 219 LSW was present, whereas at the other stations MAW was the prevailing surface water mass.

The ultra-oligotrophic situation in the Eastern Mediterranean Sea is well demonstrated in the nutrient profiles and total prokaryote analysis (in Fig. 2a,c).
Phosphate and nitrate as important nutrients for biological processes were either not detectable (phosphate, surface waters of Stn 219) or were present at extremely low concentrations at Stn 295 (phosphate: 0.03 to $0.04 \mu \mathrm{M}$, maximum nitrate concentrations $5.8 \mu \mathrm{M}$ at $1000 \mathrm{~m}$ depth). Total numbers of prokaryotes were $2.5 \times 10^{5}$ cells ml ${ }^{-1}$ in surface waters of Stn 219 and decreased by about 1 order of magnitude at $2500 \mathrm{~m}$ depth (Fig. 2a). This also applied to Stns $295(2.15 \times$ $10^{5}$ cells ml ${ }^{-1}$ at $10 \mathrm{~m}$ depth, $1.0 \times 10^{4}$ cells ml ${ }^{-1}$ at $2700 \mathrm{~m})$ and $254\left(4.37 \times 10^{5}\right.$ cells ml $\mathrm{ml}^{-1}$ at $10 \mathrm{~m}$ depth, $3.8 \times 10^{4}$ cells $\mathrm{ml}^{-1}$ at $\left.2000 \mathrm{~m}\right)$. Maximum total prokaryote abundance corresponded to the chlorophyll maxima at 100 to $150 \mathrm{~m}$ depth, as detected by the fluorometer connected to the CTD (Fig. 2b).

The analysis of clone libraries amplified with the general eubacterial primer set $27 \mathrm{~F}$ and $1387 \mathrm{R}$ resulted in 16S rDNA sequences from the Alpha-, Beta-, Gamma- and Deltaproteobacteria, the Planctomycetes, the Chaldithrix group, the Acidobacteria, the Nitrospina group, the Cyanobacteria and the Thermomicrobia, but no Bacteroidetes sequence. Thus, the results from previous studies, suggesting that general eubacterial primers are not suitable for detecting and analyzing environmental Bacteroidetes communities, were confirmed. In order to specifically amplify representatives of the Bacteroidetes from environmental samples, the 27F/Cyt1020R primer set was subsequently used for $16 \mathrm{~S}$ rDNA clone libraries. The RDPII probe match (see http://rdp.cme.msu.edu/probematch/search.jsp) and BLAST search confirmed the specificity of the Cyt1020R primer for the Bacteroidetes. When applied for amplification of Bacteroidetes sequences from environmental samples, this primer set also showed a good performance: 83 of a total of 88 DGGE band sequences and 64 of 71 16S rDNA clone sequences were assigned to the Bacteroidetes by the ARB software. A few exceptions were found within the Actinobacteria, Chloroflexaceae, Verrucomicrobia, Thermomicrobia and the OD1-OP11-WS6-TM7 group.

The horizontal and vertical variability of the Bacteroidetes community in the Eastern Mediterranean Sea was investigated using DGGE. The band patterns of DGGE gels provided a first insight into the diversity of the Bacteroidetes lineage in different depths and water masses at Stns 219, 236, 254, 265, 291, 293, and 295 (DGGE results not shown for Stns 236, 265, 291, 293, M40/3D). DGGE showed major and characteristic bands in the different water masses of the investigated stations; examples are shown for Stns 219 (SW Cyprus, Levantine Basin), 254 (Ierapetra, Cretan Passage) and 295 (Ionian Basin) in Fig. 3a-c. Although some bands were present in samples throughout the water column, several bands were depth-specific. For example, Bands 254-1, -2, -3 and -9 characterized the MAW at 

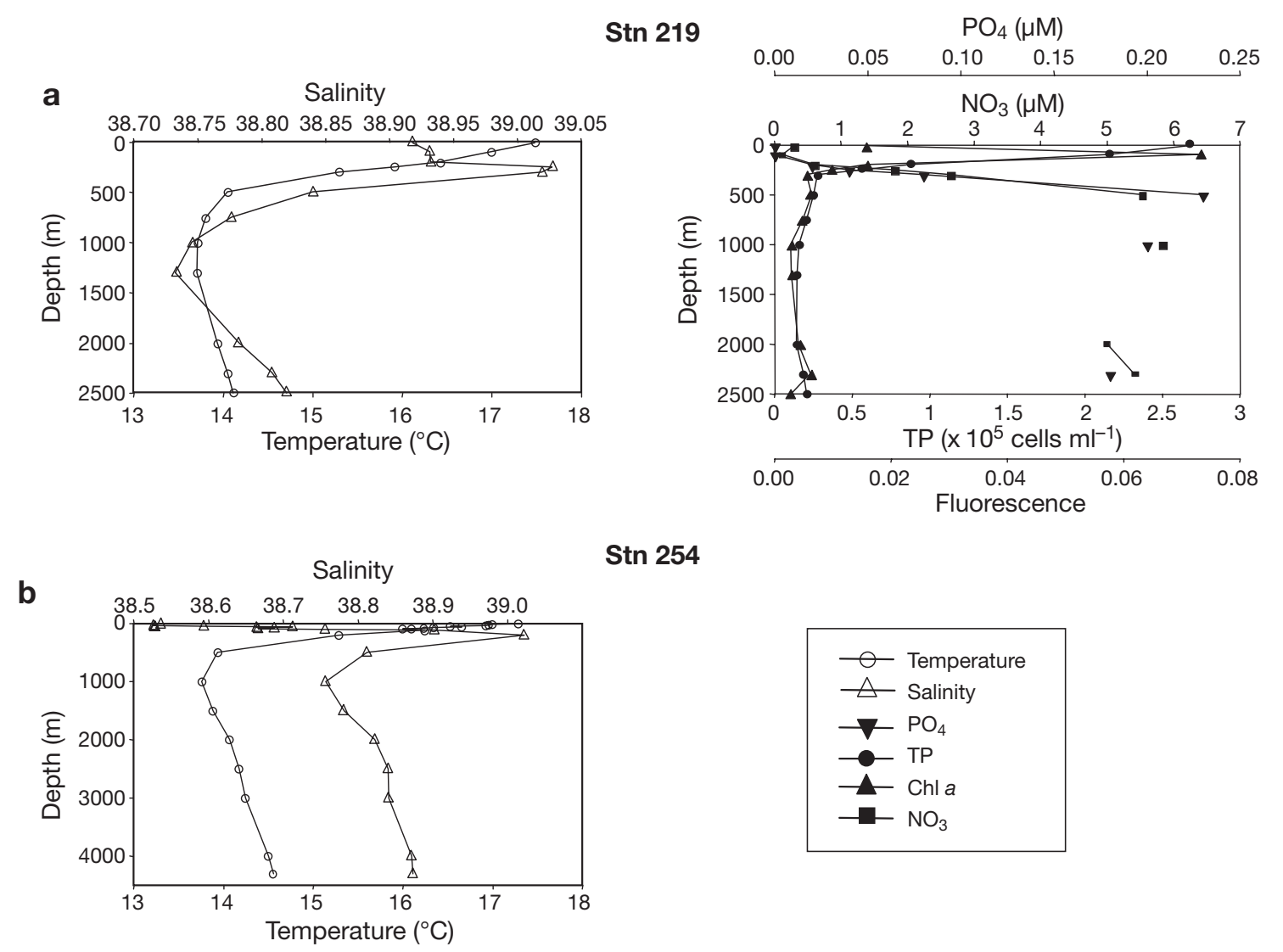

Stn 254

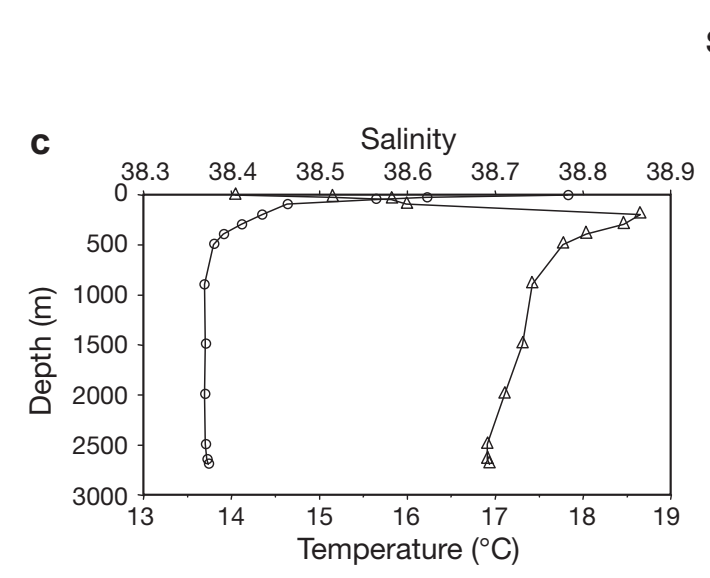

\begin{tabular}{llllll} 
Stn 295 & \multicolumn{5}{c}{$\mathrm{PO}_{4}(\mu \mathrm{M})$} \\
& 0.00 & 0.05 & 0.10 & 0.15 & 0.20
\end{tabular}

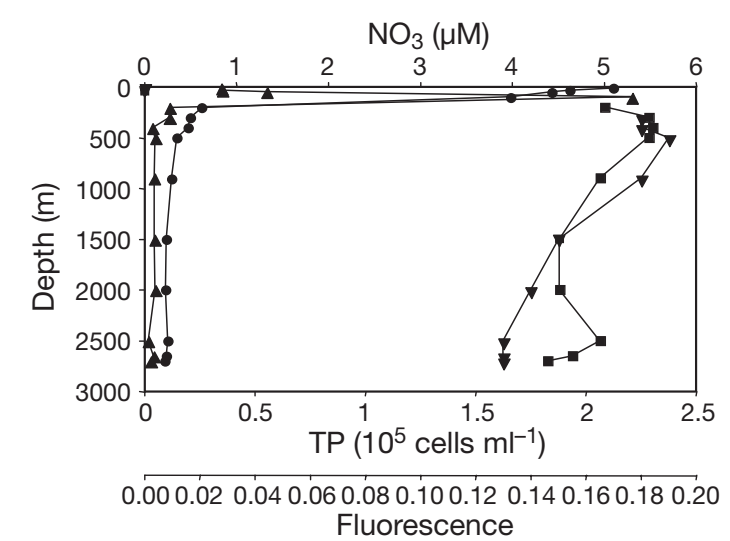

Fig. 2. Depth profiles of temperature and salinity, $\mathrm{PO}_{4}, \mathrm{NO}_{3}$ and chlorophyll a including counts of total prokaryotes (TP) at Stns 219, 254 and 295. No nutrient and TP data were available for Stn 254 (Ierapetra basin)

Stn 254 and Bands 295-1, -3, -4, -5, -6 at Stn 295, respectively. Bands $219-1,-2,-3,-4,-5$ were characteristic of surface and intermediate waters at Stn 219. Band 219-6 was typical for the LIW at Stn 219, as were Bands 254-4 and 295-2, -7, -8, -9, -10 at the respective stations. Deep water masses $\left(\mathrm{EMDW}_{\mathrm{Adr}}\right.$ and EMD$\mathrm{W}_{\text {Aeg }}$ ) were characterized by Bands 219-7, $-9,254-10$ and 295-11, -12, -13, -14. To infer Bacteroidetes sequence distribution with depth along physical water mass gradients, a cluster analysis of the DGGE bands was performed in combination with an ANOSIM based on a presence/absence matrix (Fig. 3d-f). Cluster analysis of all 3 stations investigated resulted in distinct clusters primarily according to water mass distribution. Especially at Stn 295, the individual water masses were clearly distinguished in the DGGE pro- 
a) $\operatorname{Stn} 219$

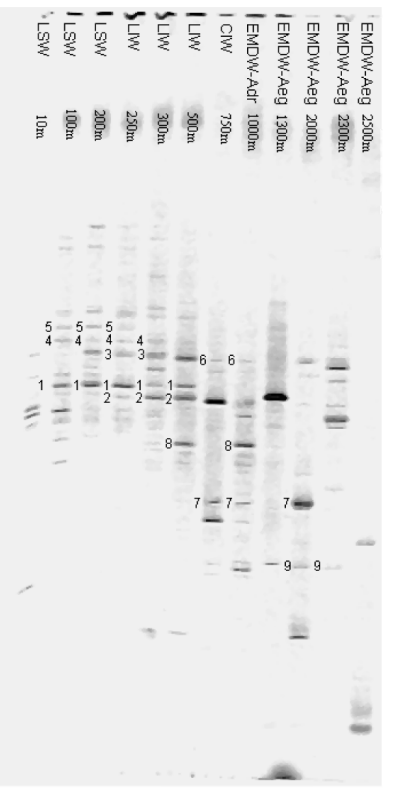

d) $\operatorname{Stn} 219$

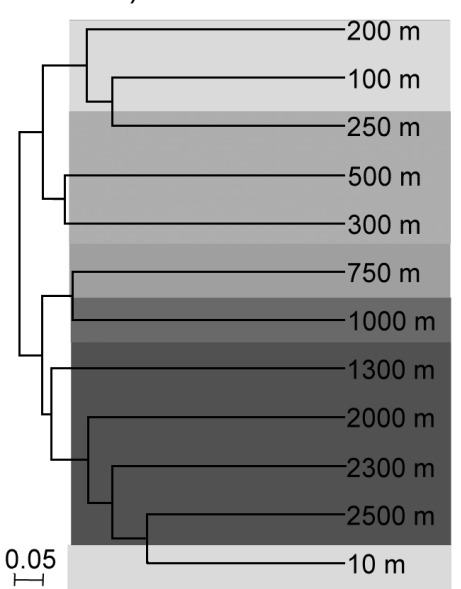

MAWILSW b) Stn 254

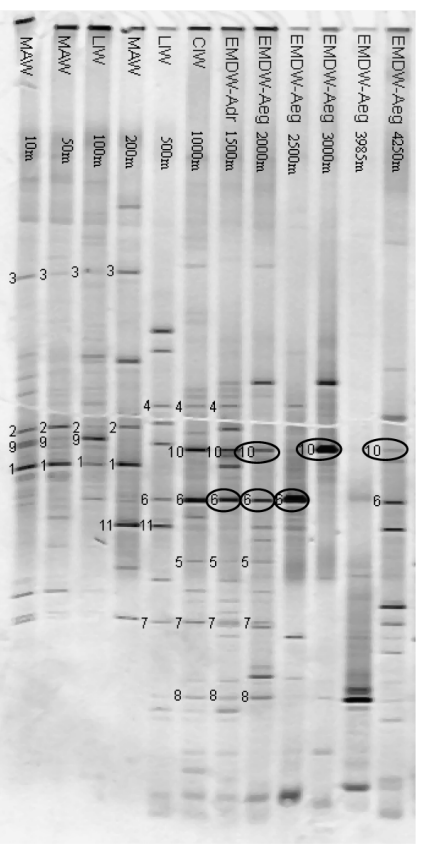

e) $\operatorname{Stn} 254$

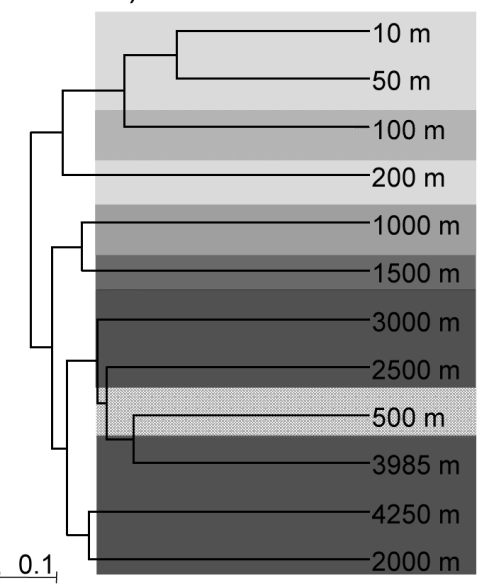

CIW
C) Stn 295

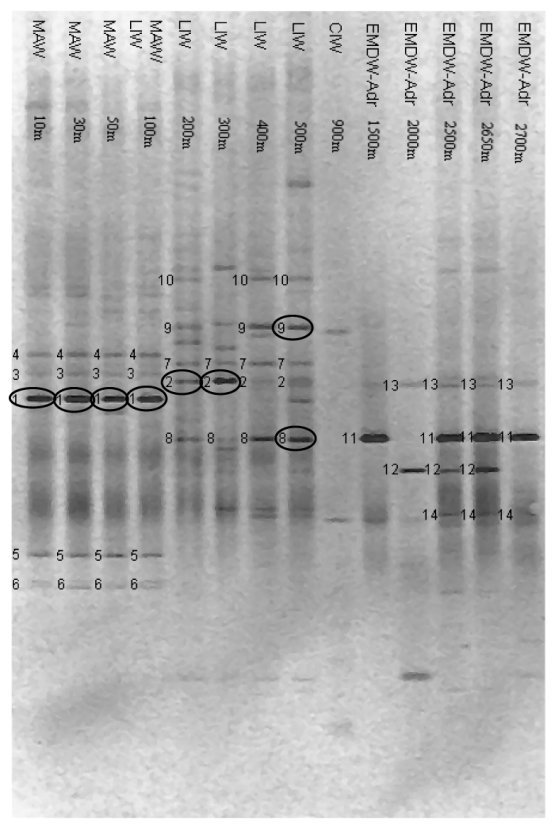

f) $\operatorname{Stn} 295$

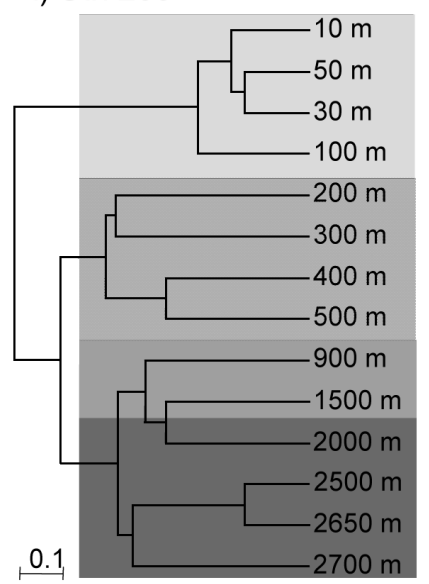

EMDW $_{\text {Aeg }}$

Fig. 3. (a-c) 16S rDNA DGGE depth profiles at Stns 219 (Levantine Basin), 254 (Ierapetra, Cretan Passage) and 295 (Ionian Basin); numbers inside gel bands indicate bands with depth-specific distribution. Circles mark bands which were excised and sequenced (boldface in Table 2). (d-f) Cluster analysis (algorithm: paired group; similarity measure: Euclidean) of DGGE gels from Stns 219, 254 and 295 based on a presence/absence matrix. Grey shading depicts water masses. MAW: Modified Atlantic Water,

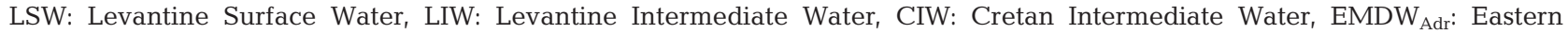

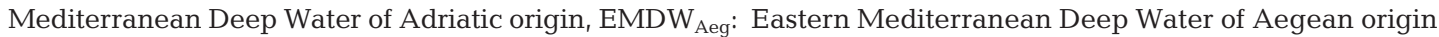

file. In general, this also applied to Stns 219 and 254. However, the $10 \mathrm{~m}$ sample clustered within the EMD$\mathrm{W}_{\text {Aeg }}$ at Stn 219, and at Stn 254 a sample from LIW (500

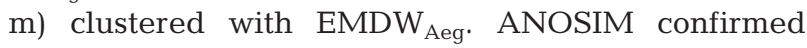
these results (Bray-Curtis distance: $\operatorname{Stn} 295, \mathrm{R}=0.72$; Stn 254, R = 0.65; Stn 219, R = 0.43).

For identification of the bacteria represented by the DGGE bands, DNA sequences of a total of 88 excised bands were determined. Table 2 shows the EMBL accession numbers and the phylogenetic affiliation of band sequences according to BLAST. Unfortunately, no sequences could be obtained from excised bands of Stn 219. The majority of sequences from DGGE bands (83) clustered within the AGG58 lineage of the Bacteroidetes phylum and were assigned to $16 \mathrm{~S}$ rDNA sequences from different environments such as the Delaware Estuary, the 
Columbia River Estuary, the Arctic and Southern Oceans and the English Channel off Plymouth. Within the AGG58 cluster, sequences from DGGE bands derived from the Mediterranean Sea clustered separately (Fig. 4).

The investigation of Bacteroidetes communities within the Mediterranean Sea based on sequences from DGGE bands was supported by $16 \mathrm{~S}$ rDNA se- quence analysis from clone libraries of selected samples. A total of 71 16S rDNA clone sequences was obtained from 3 clone libraries using the primer set 27F/1020CytR for PCR amplification. 16S rDNA cloning experiments were performed with 2 samples from different water masses at Stn 219 (LIW-300 m and $\mathrm{EMDW}_{\mathrm{Aeg}}-2300 \mathrm{~m}$ ) and 1 sample from Stn 254

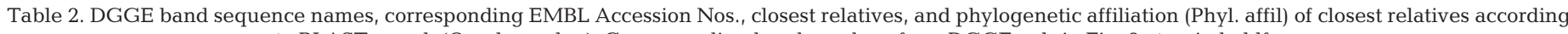
to BLAST search (Overl: overlap). Corresponding band numbers from DGGE gels in Fig. 3a to $\mathrm{c}$ in boldface

\begin{tabular}{|c|c|c|c|c|c|c|c|}
\hline DGGE band & Acc. No. & $\begin{array}{l}\text { Length } \\
\text { (nt) }\end{array}$ & Closest relative & $\begin{array}{l}\text { Acc. No. } \\
\text { closest relative }\end{array}$ & $\begin{array}{c}\text { Overl } \\
\text { (nt) }\end{array}$ & $\begin{array}{l}\text { Identity } \\
(\%)\end{array}$ & $\begin{array}{l}\text { Phyl. } \\
\text { affil }\end{array}$ \\
\hline 254-D-EMDW Adr -19 & AM411224 & 159 & Uncultured bacterium clone FS266-38B-03 & DQ513080 & 157 & 98 & Bacteroidetes \\
\hline \multicolumn{8}{|l|}{ Band 254-6, $1500 \mathrm{~m}$} \\
\hline 254-D-EMDW $\mathrm{Adr}_{\mathrm{Ar}}-22$ & AM411225 & 160 & Uncultured bacterium clone FS266-38B-03 & DQ513080 & 155 & 96 & Bacteroidetes \\
\hline \multicolumn{8}{|l|}{ Band $254-10,2000 \mathrm{~m}$} \\
\hline 254-D-EMDW Aeg -24 & AM411227 & 165 & Uncultured bacterium clone FS266-38B-03 & DQ513080 & 162 & 98 & Bacteroidetes \\
\hline \multicolumn{8}{|l|}{ Band 254-6, $2000 \mathrm{~m}$} \\
\hline 254-D-EMDW Aeg $^{-27}$ & AM411229 & 153 & Uncultured bacterium clone FS266-38B-03 & DQ513080 & 149 & 96 & Bacteroidetes \\
\hline \multicolumn{8}{|l|}{ Band $254-6,2500 \mathrm{~m}$} \\
\hline 254-D-EMDW Aeg -28 & AM411232 & 142 & Uncultured bacterium BAx5 16S ribosomal RNA gene & AF087086 & 123 & 87 & Bacteroidetes \\
\hline 254-D-EMDW Aeg -29 & AM411228 & 155 & Uncultured bacterium clone FS266-38B-03 & DQ513080 & 149 & 96 & Bacteroidetes \\
\hline \multicolumn{8}{|l|}{ Band 254-10, $3000 \mathrm{~m}$} \\
\hline 254-D-EMDW Aeg -30 & AM398940 & 136 & Sponge bacterium Zo24 & AY948380 & 133 & 97 & Actinobacteria \\
\hline 254-D- EMDW $\mathrm{Adr}_{\mathrm{Ar}}-33$ & AM411226 & 160 & Uncultured bacterium clone FS266-38B-03 & DQ513080 & 154 & 95 & Bacteroidetes \\
\hline 254-D-EMDW Aeg -34 & AM411230 & 150 & Marine bacterium KMM 6048 16S ribosomal RNA gene & AY753911 & 144 & 95 & Bacteroidetes \\
\hline \multicolumn{8}{|l|}{ Band $254-10,4250 \mathrm{~m}$} \\
\hline 254-D-EMDW Aeg -35 & AM411231 & 143 & Uncultured bacterium gene for $16 \mathrm{~S}$ rRNA, clone: AL-5 & AB232535 & 139 & 96 & Bacteroidetes \\
\hline 254-D-EMDW Aeg -36 & AM411233 & 149 & Flavobacterium sp. CI33 16S ribosomal RNA gene & DQ530100 & 141 & 93 & Bacteroidetes \\
\hline $254-\mathrm{D}-1^{\mathrm{a}}$ & AM411238 & 148 & Uncultured Bacteroidetes bacterium clone FFW55 & AY828423 & 143 & 95 & Bacteroidetes \\
\hline $254-\mathrm{D}-2^{\mathrm{a}}$ & AM411236 & 148 & Uncultured Bacteroidetes bacterium clone FFW55 & AY828423 & 145 & 96 & Bacteroidetes \\
\hline $254-\mathrm{D}-3^{\mathrm{a}}$ & AM411237 & 150 & Uncultured Bacteroidetes bacterium clone FFW55 & AY828423 & 150 & 98 & Bacteroidetes \\
\hline $254-\mathrm{D}-6^{\mathrm{a}}$ & AM411246 & 130 & Uncultured Bacteroidetes bacterium clone FFW55 & AY828423 & 119 & 91 & Bacteroidetes \\
\hline $254-D-10^{a}$ & AM411242 & 152 & Uncultured bacterium clone FS266-38B-03 & DQ513080 & 139 & 91 & Bacteroidetes \\
\hline $254-D-12^{a}$ & AM411235 & 159 & Uncultured bacterium clone FS266-38B-03 & DQ513080 & 156 & 97 & Bacteroidetes \\
\hline $254-D-13^{a}$ & AM411247 & 133 & Uncultured Flavobacteriaceae bacterium clone ESP200-K10-6 & DQ810543 & 124 & 93 & Bacteroidetes \\
\hline $254-\mathrm{D}-14^{\mathrm{a}}$ & AM411244 & 140 & Uncultured bacterium clone FS266-38B-03 & DQ513080 & 128 & 90 & Bacteroidetes \\
\hline $254-\mathrm{D}-15^{\mathrm{a}}$ & AM411240 & 156 & Uncultured bacterium clone FS266-38B-03 & DQ513080 & 149 & 95 & Bacteroidetes \\
\hline $254-D-16^{a}$ & AM411234 & 157 & Uncultured bacterium clone FS266-38B-03 & DQ513080 & 153 & 96 & Bacteroidetes \\
\hline $254-\mathrm{D}-17^{\mathrm{a}}$ & AM411239 & 144 & Uncultured bacterium clone FS266-38B-03 & DQ513080 & 138 & 95 & Bacteroidetes \\
\hline $254-\mathrm{D}-18^{\mathrm{a}}$ & AM411241 & 158 & Uncultured bacterium clone FS266-38B-03 & DQ513080 & 151 & 95 & Bacteroidetes \\
\hline $254-D-19^{a}$ & AM411245 & 126 & Uncultured Bacteroidetes bacterium clone PLY-P1-17 & AY354711 & 122 & 96 & Bacteroidetes \\
\hline $254-\mathrm{D}-20^{\mathrm{a}}$ & AM411243 & 150 & Marine bacterium KMM 6048 & AY753911 & 143 & 95 & Bacteroidetes \\
\hline M40/3D-D-1 ${ }^{\mathrm{b}}$ & AM411250 & 136 & Uncultured Bacteroidetes bacterium clone FFW55 & AY828423 & 134 & 97 & Bacteroidetes \\
\hline M40/3D-D-11 ${ }^{\mathrm{b}}$ & AM411248 & 140 & Uncultured bacterium clone FS266-38B-03 & DQ513080 & 135 & 96 & Bacteroidetes \\
\hline M40/3D-D-12 & AM411249 & 158 & Uncultured bacterium clone FS266-38B-03 & DQ513080 & 143 & 90 & Bacteroidetes \\
\hline M40/3D-D-14 ${ }^{\mathrm{b}}$ & AM411251 & 57 & Uncultured bacterium clone SIMO-1962 & AY711328 & 52 & 91 & Bacteroidetes \\
\hline 295-D-MAW-1 & AM411284 & 151 & Uncultured Bacteroidetes bacterium clone FFW55 & AY828423 & 148 & 98 & Bacteroidetes \\
\hline \multicolumn{8}{|l|}{ Band 295-1, $10 \mathrm{~m}$} \\
\hline 295-D-MAW-2 & AM411282 & 158 & Uncultured Bacteroidetes bacterium clone FFW55 & AY828423 & 155 & 98 & Bacteroidetes \\
\hline \multicolumn{8}{|l|}{ Band 295-1, $30 \mathrm{~m}$} \\
\hline 295-D-MAW-3 & AM411281 & 158 & Uncultured Bacteroidetes bacterium clone FFW55 & AY828423 & 155 & 98 & Bacteroidetes \\
\hline \multicolumn{8}{|l|}{ Band 295-1, $50 \mathrm{~m}$} \\
\hline 295-D-LIW-4 & AM411285 & 157 & Uncultured Bacteroidetes bacterium clone FFW55 & AY828423 & 155 & 98 & Bacteroidetes \\
\hline \multicolumn{8}{|l|}{ Band 295-1, $100 \mathrm{~m}$} \\
\hline 295-D-LIW-5 & AM411294 & 161 & Uncultured bacterium clone FS266-38B-03 & DQ513080 & 156 & 96 & Bacteroidetes \\
\hline \multicolumn{8}{|l|}{ Band 295-2, $200 \mathrm{~m}$} \\
\hline 295-D-LIW-6 & AM411283 & 158 & Uncultured bacterium clone FS266-38B-03 & DQ513080 & 154 & 97 & Bacteroidetes \\
\hline \multicolumn{8}{|l|}{ Band 295-2, $300 \mathrm{~m}$} \\
\hline 295-D-LIW-7 & AM411293 & 156 & Uncultured Bacteroidetes bacterium clone SBI04_186 & DQ186942 & 145 & 92 & Bacteroidetes \\
\hline 295-D-LIW-8 & AM411289 & 153 & Uncultured Bacteroidetes bacterium clone FFP61 & AY830006 & 146 & 95 & Bacteroidetes \\
\hline 295-D-LIW-9 & AM411292 & 157 & Uncultured Bacteroidetes bacterium clone FFP61 & AY830006 & 148 & 94 & Bacteroidetes \\
\hline
\end{tabular}


(EMDW ${ }_{\text {Aeg }}-2000 \mathrm{~m}$ depth). Affiliation of selected whole insert 16S rDNA clones (approx. $1000 \mathrm{nt}$ from 219-CEMDW-Aeg-15，219-C-LIW-40 and 2119-C-LIW-49) was identical to that of the 5 ' terminal fragments comprising approx. $400 \mathrm{nt}$. Thus, short fragments were determined for the majority of the environmental clones. Sequences from environmental clones were mainly as- signed to the Bacteroidetes (Table 3) and branched almost exclusively within the AGG58 cluster (Fig. 4). Closest relatives were sampled from various environments: the English Channel off Plymouth, surface waters near Sapelo Island, the Columbia River Estuary, the Southern Ocean, the Sargasso Sea, the Pacific Ocean off San Pedro (California), from ridge flank crustal flu-

Table 2 (continued)

\begin{tabular}{|c|c|c|c|c|c|c|c|}
\hline DGGE band & Acc. No. & $\begin{array}{l}\text { Length } \\
\text { (nt) }\end{array}$ & Closest relative & $\begin{array}{l}\text { Acc. No. } \\
\text { closest relative }\end{array}$ & $\begin{array}{c}\text { Overl } \\
\text { (nt) }\end{array}$ & $\begin{array}{l}\text { Identity } \\
(\%)\end{array}$ & $\begin{array}{l}\text { Phyl. } \\
\text { affil }\end{array}$ \\
\hline \multicolumn{8}{|l|}{ Band 295-9, $500 \mathrm{~m}$} \\
\hline 295-D-LIW-10 & AM411291 & 125 & Uncultured Flavobacteriaceae bacterium clone ESP200-K10-6 & DQ810543 & 111 & 88 & Bacteroidetes \\
\hline 295-D-LIW-11 & AM411286 & 165 & Uncultured bacterium clone FS266-38B-03 & DQ513080 & 161 & 97 & Bacteroidetes \\
\hline \multicolumn{8}{|l|}{ Band $295-8,500 \mathrm{~m}$} \\
\hline 295-D-CIW-12 & AM398930 & 147 & Uncultured Chloroflexaceae group bacterium Arctic95A-18 & AF355054 & 140 & 95 & Chloroflexi \\
\hline 295-D-EMDW $\mathrm{Adr}_{\mathrm{A}}-13$ & AM411279 & 160 & Uncultured bacterium clone FS266-38B-03 & DQ513080 & 157 & 98 & Bacteroidetes \\
\hline 295-D-EMDW Adr $_{14}-14$ & AM411288 & 154 & Marine bacterium KMM 6048 & AY753911 & 147 & 95 & Bacteroidetes \\
\hline 295-D-EMDW $\mathrm{Adr}-15$ & AM411287 & 157 & Marine bacterium KMM 6048 & AY753911 & 155 & 98 & Bacteroidetes \\
\hline 295-D-EMDW $\mathrm{Adr}-16$ & AM398931 & 135 & Uncultured Chloroflexi bact. isolate DGGE gel band SuluC14 & DQ273982 & 133 & 98 & Chloroflexi \\
\hline 295-D-EMDW $\mathrm{Adr}-17$ & AM411290 & 161 & Uncultured bacterium clone FS266-38B-03 & DQ513080 & 150 & 93 & Bacteroidetes \\
\hline 295-D-EMDW $W_{\text {Adr }}-18$ & AM411215 & 129 & Uncultured Flavobacteriaceae bacterium clone ESP450-K6II-56 & DQ810695 & 116 & 89 & Bacteroidetes \\
\hline 295-D-EMDW Adr $^{-19}$ & AM411295 & 153 & Uncultured bacterium clone FS266-38B-03 & DQ513080 & 150 & 98 & Bacteroidetes \\
\hline 295-D-EMDW $\mathrm{Adr}-20$ & AM411280 & 71 & Uncultured Bacteroidetes bacterium clone FFW55 & AY828423 & 66 & 92 & Bacteroidetes \\
\hline 236-D-LSW-1 & AM411253 & 152 & Uncultured Bacteroidetes bacterium clone FFW5 & AY828423 & 148 & 97 & Bacteroidetes \\
\hline 236-D-LSW-2 & AM411259 & 134 & Uncultured Bacteroidetes bacterium clone FFW55 & AY828423 & 132 & 98 & Bacteroidetes \\
\hline 236-D-LSW-3 & AM411252 & 150 & Uncultured Bacteroidetes bacterium clone FFW55 & AY828423 & 147 & 98 & Bacteroidetes \\
\hline 236-D-LIW-5 & AM411255 & 160 & Uncultured Bacteroidetes bacterium clone PLY-P1-17 & AY354711 & 156 & 97 & Bacteroidetes \\
\hline 236-D-LIW-6 & AM411256 & 152 & Uncultured bacterium clone FS266-38B-03 & DQ513080 & 141 & 92 & Bacteroidetes \\
\hline 236-D-LIW-7 & AM411258 & 153 & Uncultured bacterium clone FS266-38B-03 & DQ513080 & 147 & 96 & Bacteroidetes \\
\hline 236-D-LIW-8 & AM411260 & 174 & Uncultured bacterium clone E53-156 & DQ639403 & 169 & 97 & Bacteroidetes \\
\hline 236-D-LIW-9 & AM411265 & 146 & Uncultured bacterium clone CTD005-74B-02 & AY704387 & 145 & 99 & Bacteroidetes \\
\hline 236-D-EMDW $\mathrm{Adr}_{\mathrm{Ad}}-13$ & AM411263 & 135 & Flavobacterium columnare & AY747592 & 133 & 98 & Bacteroidetes \\
\hline 236-D-EMDW Aeg $^{-17}$ & AM411257 & 148 & Uncultured bacterium clone FS266-38B-03 & DQ513080 & 136 & 91 & Bacteroidetes \\
\hline 236-D-EMDW Aeg $^{-18}$ & AM411264 & 108 & Flavobacteriaceae bacterium LZXC41 & DQ659086 & 107 & 99 & Bacteroidetes \\
\hline 236-D-EMDW Aeg $^{-20}$ & AM411254 & 163 & Uncultured bacterium clone FS266-38B-03 & DQ513080 & 160 & 98 & Bacteroidetes \\
\hline 236-D-EMDW ${ }_{\text {Aeq }}-21$ & AM411261 & 157 & Uncultured bacterium clone SG2-42 & AY135906 & 152 & 96 & Bacteroidetes \\
\hline 236-D-EMDW Aeg $^{-22}$ & AM411262 & 157 & Chryseobacterium sp. RHA2-9 & DQ673672 & 154 & 98 & Bacteroidetes \\
\hline 291-D-LIW-2 & AM411217 & 165 & Uncultured Bacteroidetes bacterium clone FFW55 & AY828423 & 160 & 96 & Bacteroidetes \\
\hline 291-D-LIW-3 & AM411223 & 100 & Uncultured Cytophagales bacterium clone CD2C7 & AY038572 & 94 & 94 & Bacteroidetes \\
\hline 291-D-LIW-4 & AM411214 & 152 & Uncultured Bacteroidetes bacterium clone FFP61 & AY830006 & 147 & 96 & Bacteroidetes \\
\hline 291-D-LIW-5 & AM411213 & 169 & Uncultured bacterium clone WLB16-196 & DQ015861 & 150 & 88 & Bacteroidetes \\
\hline 291-D-LIW-6 & AM411219 & 167 & Uncultured Cytophaga sp. & AJ635360 & 161 & 96 & Bacteroidetes \\
\hline 291-D-LIW-7 & AM411218 & 165 & Uncultured bacterium clone A714014 & AY907801 & 161 & 97 & Bacteroidetes \\
\hline 291-D-CIW-8 & AM411216 & 145 & Uncultured bacterium clone E53-156 & DQ639403 & 138 & 95 & Bacteroidetes \\
\hline 291-D-EMDW Aeg $_{\text {-11 }}$ & AM411222 & 118 & Uncultured Flavobacteriaceae bacterium clone ESP200-K10-6 & DQ810543 & 112 & 94 & Bacteroidetes \\
\hline 291-D-EMDW Aeg $^{-13}$ & AM411220 & 154 & Uncultured bacterium clone FS266-38B-03 & DQ513080 & 141 & 91 & Bacteroidetes \\
\hline 291-D-EMDW ${ }_{\text {Aeg }}-14$ & AM411221 & 132 & Uncultured Flavobacteriaceae bacterium clone ESP200-K10-6 & DQ810543 & 132 & 100 & Bacteroidetes \\
\hline 293-D-MAW-2 & AM411266 & 159 & Uncultured Bacteroidetes bacterium clone FFW55 & AY828423 & 158 & 99 & Bacteroidetes \\
\hline 293-D-MAW-3 & AM411272 & 140 & Uncultured Bacteroidetes bacterium clone ECS-R21 & DQ656214 & 137 & 97 & Bacteroidetes \\
\hline 293-D-MAW-4 & AM411275 & 154 & uncultured Bacteroidetes bacterium MTAE19 & AJ619057 & 144 & 93 & Bacteroidetes \\
\hline 293-D-MAW-5 & AM411273 & 157 & Uncultured Bacteroidetes bacterium clone ECS-R21 & DQ656214 & 149 & 94 & Bacteroidetes \\
\hline 293-D-LIW-7 & AM411271 & 146 & Uncultured bacterium clone FS266-38B-03 & DQ513080 & 144 & 98 & Bacteroidetes \\
\hline 293-D-CIW-10 & AM398932 & 142 & Arthrobacter sp. SMB28 & DQ868689 & 134 & 94 & Actinobacteria \\
\hline 293-D-CDW-11 & AM411276 & 144 & uncultured Bacteroidetes bacterium MTAE19 & AJ619057 & 132 & 91 & Bacteroidetes \\
\hline 293-D-CDW-12 & AM411269 & 164 & Uncultured Bacteroidetes bacterium clone SC001B77 & AY807715 & 164 & 100 & Bacteroidetes \\
\hline 293-D-CDW-17 & AM411270 & 160 & Uncultured bacterium clone FS266-38B-03 & DQ513080 & 156 & 97 & Bacteroidetes \\
\hline 293-D-CDW-18 & AM411277 & 144 & Uncultured bacterium clone LC1537B-77 & DQ272585 & 131 & 90 & Bacteroidetes \\
\hline 293-D-BRINE-19 & AM411267 & 152 & Uncultured bacterium clone E53-156 & DQ639403 & 151 & 99 & Bacteroidetes \\
\hline 293-D-BRINE-20 & AM411268 & 157 & Capnocytophaga sp. AHN9528 & DQ012324 & 154 & 98 & Bacteroidetes \\
\hline 293-D-BRINE-21 & AM411278 & 136 & Uncultured bacterium clone LC1537B-77 & DQ272585 & 126 & 92 & Bacteroidetes \\
\hline 293-D-BRINE-23 & AM398941 & 155 & Brevibacterium linens AC825 & AY017070 & 154 & 99 & Actinobacteria \\
\hline 293-D-BRINE-25 & AM411274 & 165 & Flavobacterium sp. B11 & AJ518814 & 168 & 98 & Bacteroidetes \\
\hline
\end{tabular}




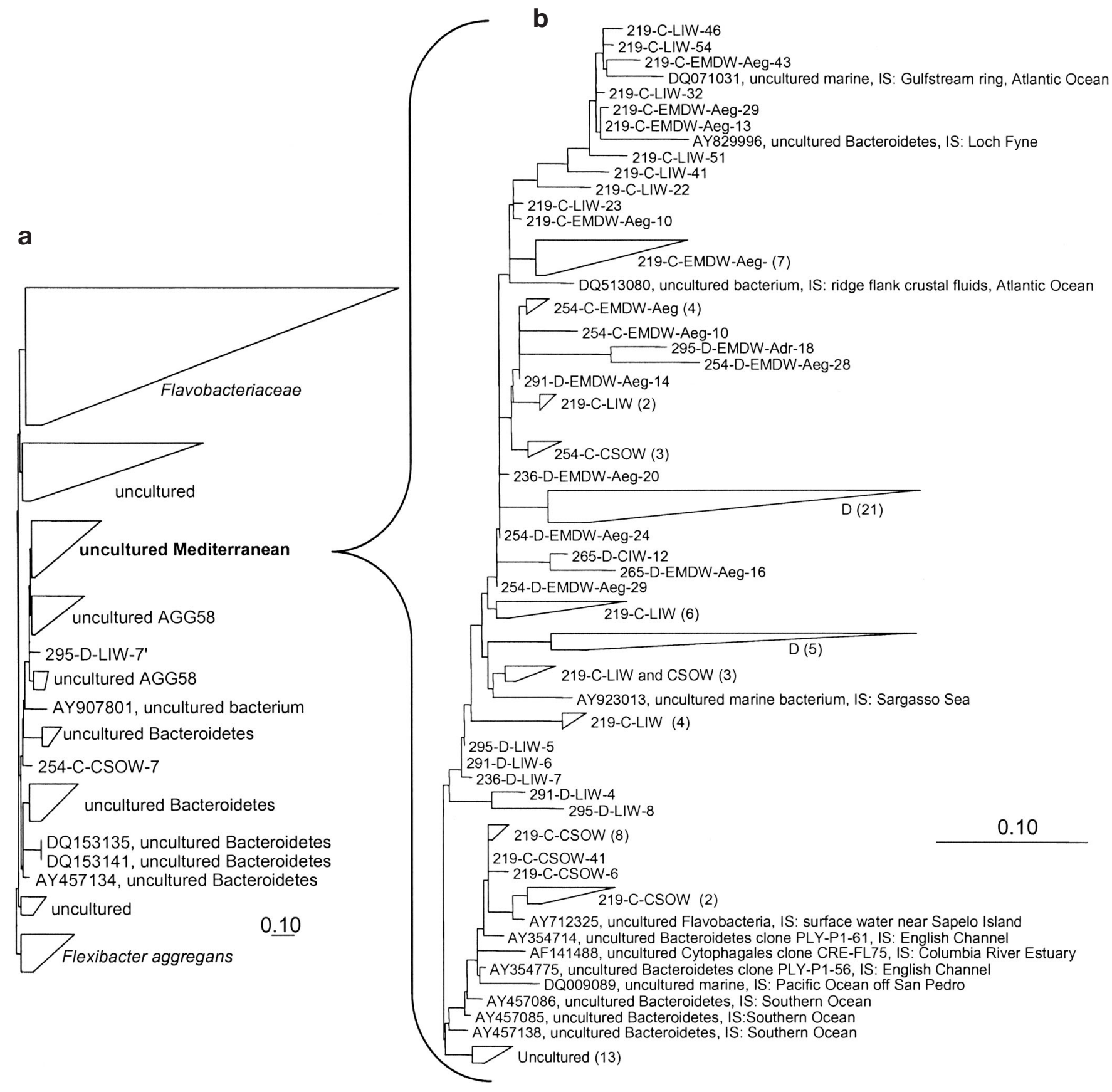

Fig. 4. (a) Phylogenetic 16S rDNA tree (parsimony, exported from ARB) showing position of 'Mediterranean' cluster (boldface) in Bacteroidetes phylum. (b) High-resolution phylogenetic 16S rDNA tree (parsimony, exported from ARB) of 'Mediterranean' cluster showing majority of sequences obtained from environmental clones and DGGE bands during this study as well as reference sequences from closest relatives; 219/236/254/265/M40-3D/291/293/295: isolation source/station; C/D: origin of sequence (environmental clones/DGGE); LIW/EMDW-Adr/EMDW-Aeg: corresponding water masses; numbers in parentheses: no. of sequences within wedges; In reference sequences: IS: isolation source; other abbreviations as in Fig. 3 key

ids, the Gulf Stream, Loch Fyne (Scotland) after nutrient addition, and from the Delaware River Estuary. Because of the limited number of clones analyzed from each water mass (219-LIW: 29, 219-EMDW Aeg $_{2}$ 26, 254EMDW $\left._{\text {Aeg }}: 16\right)$ analytical rarefaction analysis combined with a regression analysis was performed in order to in- fer the total Bacteroidetes diversity covered by clone libraries. For rarefaction, it was assumed that 1 OTU is formed by sequences presenting a similarity equal to or greater than $99 \%$ (Fig. 5). Results from rarefaction/regression analysis showed a coverage of approximately half the expected number of OTUs in the respective 


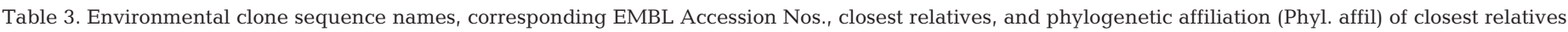
according to BLAST search (Overl: overlap). 219-C-LIW: $\mathrm{n}=29,219-\mathrm{C}-\mathrm{EMDW}_{\text {Aeg }}: \mathrm{n}=26,254-\mathrm{C}-\mathrm{EMDW}_{\text {Aeg }}: \mathrm{n}=16$

\begin{tabular}{|c|c|c|c|c|c|c|c|}
\hline Clone & $\begin{array}{l}\text { Acc. } \\
\text { No. }\end{array}$ & $\begin{array}{l}\text { Length } \\
\text { (nt) }\end{array}$ & Closest relative & $\begin{array}{c}\text { Acc. No. } \\
\text { Closest relative }\end{array}$ & $\begin{array}{c}\text { Overl } \\
\text { (nt) }\end{array}$ & $\begin{array}{l}\text { Identity } \\
(\%)\end{array}$ & Phyl. affil \\
\hline 219-C-LIW-1 & AM411296 & 373 & Uncultured marine bacterium clone SPOTSFEB02_70m25 & DQ009434 & 361 & 96 & Bacteroidetes \\
\hline 219-C-LIW-2 & AM411298 & 357 & Uncultured bacterium clone FS266-38B-03 & DQ513080 & 337 & 94 & Bacteroidetes \\
\hline 219-C-LIW-3 & AM411313 & 414 & Uncultured bacterium clone A714014 & AY907801 & 397 & 95 & Bacteroidetes \\
\hline 219-C-LIW-21 & AM411321 & 157 & Uncultured Bacteroidetes bacterium clone SBI04_174 & DQ186940 & 156 & 99 & Bacteroidetes \\
\hline 219-C-LIW-22 & AM411312 & 323 & Uncultured Bacteroidetes bacterium clone FFW19 & AY830011 & 301 & 93 & Bacteroidetes \\
\hline 219-C-LIW-23 & AM411613 & 454 & Uncultured bacterium clone FS266-38B-03 & DQ513080 & 448 & 98 & Bacteroidetes \\
\hline 219-C-LIW-25 & AM411301 & 293 & Uncultured marine bacterium clone D92_53 & AY923013 & 277 & 94 & Bacteroidetes \\
\hline 219-C-LIW-26 & AM411310 & 268 & Uncultured bacterium clone FS266-38B-03 & DQ513080 & 262 & 97 & Bacteroidetes \\
\hline 219-C-LIW-29 & AM411299 & 337 & Uncultured bacterium clone FS266-38B-03 & DQ513080 & 331 & 98 & Bacteroidetes \\
\hline 219-C-LIW-30 & AM411297 & 398 & Uncultured marine bacterium clone D92_53 & AY923013 & 372 & 93 & Bacteroidetes \\
\hline 219-C-LIW-31 & AM411306 & 353 & Uncultured Bacteroidetes bacterium clone FFW80 & AY828437 & 338 & 95 & Bacteroidetes \\
\hline 219-C-LIW-32 & AM411320 & 176 & Uncultured Bacteroidetes bacterium clone FFP21 & AY829996 & 175 & 99 & Bacteroidetes \\
\hline 219-C-LIW-34 & AM411303 & 399 & Uncultured marine bacterium clone SPOTSFEB02_70m25 & DQ009434 & 369 & 97 & Bacteroidetes \\
\hline 219-C-LIW-36 & AM411311 & 346 & Uncultured Bacteroidetes bacterium clone FFW80 & AY828437 & 335 & 96 & Bacteroidetes \\
\hline 219-C-LIW-37 & AM411302 & 399 & Uncultured Bacteroidetes bacterium clone JL-ETNP-Z67 & AY726974 & 389 & 97 & Bacteroidetes \\
\hline 219-C-LIW-38 & AM411300 & 455 & Uncultured marine bacterium clone D92_53 & AY923013 & 426 & 93 & Bacteroidetes \\
\hline 219-C-LIW-39 & AM411305 & 432 & Uncultured Cytophagales Arctic97A-17 & AF354617 & 425 & 98 & Bacteroidetes \\
\hline 219-C-LIW-40 & AM411308 & 444 & Uncultured marine bacterium clone Chl1.45 & DQ071058 & 418 & 94 & Bacteroidetes \\
\hline 219-C-LIW-41 & AM411314 & 419 & Uncultured marine bacterium clone D92_53 & AY923013 & 394 & 94 & Bacteroidetes \\
\hline 219-C-LIW-43 & AM411315 & 342 & Uncultured bacterium clone FS266-38B-03 & DQ513080 & 312 & 91 & Bacteroidetes \\
\hline 29-C-LIW-44 & AM411319 & 139 & Uncultured bacterium clone FS266-38B-03 & DQ513080 & 134 & 96 & Bacteroidetes \\
\hline 219-C-LIW-45 & AM411317 & 228 & Uncultured bacterium clone FS266-38B-03 & DQ513080 & 223 & 97 & Bacteroidetes \\
\hline 219-C-LIW-46 & AM411307 & 394 & Uncultured marine bacterium clone Chl1.10 & DQ071031 & 377 & 95 & Bacteroidetes \\
\hline 219-C-LIW-47 & AM411322 & 376 & Uncultured bacterium clone HF200_E5_P1 & DQ300888 & 371 & 98 & Bacteroidetes \\
\hline 219-C-LIW-49 & AM411309 & 404 & Uncultured bacterium clone FS266-38B-03 & DQ513080 & 392 & 97 & Bacteroidetes \\
\hline 219-C-LIW-52 & AM398933 & 435 & Unidentified eubacterium clone SAR307 & U20798 & 428 & 98 & Chloroflexi \\
\hline 219-C-LIW-54 & AM411316 & 291 & Uncultured marine bacterium clone Chl1.10 & DQ071031 & 279 & 95 & Bacteroidetes \\
\hline 219-C-LIW-57 & AM411304 & 365 & Uncultured bacterium clone FS266-38B-03 & DQ513080 & 359 & 98 & Bacteroidetes \\
\hline 219-C-LIW-59 & AM411318 & 331 & Uncultured marine bacterium clone Chl1.10 & DQ071031 & 312 & 94 & Bacteroidetes \\
\hline 219-C-EMDW Aeg -1 & AM411347 & 137 & Uncultured Bacteroidetes bacterium clone SBI04_174 & DQ186940 & 137 & 100 & Bacteroidetes \\
\hline 219-C-EMDW Aeg $^{-2}$ & AM411348 & 113 & Uncultured Flavobacteria bacterium clone SIMO-788 & AY712325 & 107 & 94 & Bacteroidetes \\
\hline 219-C-EMDW Aeg $^{-3}$ & AM411340 & 325 & Uncultured bacterium clone FS266-38B-03 & DQ513080 & 316 & 97 & Bacteroidetes \\
\hline 219-C-EMDW Aeg $^{-4}$ & AM411342 & 376 & Uncultured marine bacterium clone SPOTSAPR01_5m159 & DQ009089 & 372 & 98 & Bacteroidetes \\
\hline 219-C-EMDW Aeg $^{-6}$ & AM411331 & 466 & Uncultured marine bacterium clone SPOTSAPR01_5m159 & DQ009089 & 457 & 98 & Bacteroidetes \\
\hline 219-C-EMDW $\mathrm{Aeg}^{-7}$ & AM411341 & 417 & Uncultured marine bacterium clone SPOTSAPR01_5m159 & DQ009089 & 408 & 97 & Bacteroidetes \\
\hline 219-C-EMDW ${ }_{\text {Aeg }}-10$ & AM411345 & 165 & Uncultured bacterium clone FS266-38B-03 & DQ513080 & 160 & 96 & Bacteroidetes \\
\hline 219-C-EMDW Aeg $^{-11}$ & AM411343 & 397 & Uncultured marine bacterium clone SPOTSAPR01_5m159 & DQ009089 & 391 & 98 & Bacteroidetes \\
\hline 219-C-EMDW Aeg $^{-12}$ & AM411326 & 445 & Uncultured Flavobacteria bacterium clone SIMO-788 & AY712325 & 442 & 99 & Bacteroidetes \\
\hline 219-C-EMDW Aeg $^{-13}$ & AM411346 & 197 & Uncultured Bacteroidetes bacterium clone FFP21 & AY829996 & 196 & 99 & Bacteroidetes \\
\hline 219-C-EMDW Aeg -14 & AM411334 & 364 & Uncultured bacterium clone FS266-38B-03 & DQ513080 & 355 & 97 & Bacteroidetes \\
\hline 219-C-EMDW Aeg $^{-15}$ & AM411335 & 470 & Uncultured bacterium clone FS266-38B-03 & DQ513080 & 460 & 97 & Bacteroidetes \\
\hline 219-C-EMDW ${ }_{\text {Aeg }}-19$ & AM411332 & 396 & Uncultured marine bacterium clone SPOTSAPR01_5m159 & DQ009089 & 389 & 98 & Bacteroidetes \\
\hline 219-C-EMDW Aeg $^{-20}$ & AM411327 & 455 & Uncultured bacterium clone FS266-38B-03 & DQ513080 & 447 & 98 & Bacteroidetes \\
\hline 219-C-EMDW Aeg $^{-21}$ & AM411325 & 459 & Uncultured marine bacterium clone SPOTSAPR01_5m159 & DQ009089 & 454 & 98 & Bacteroidetes \\
\hline 219-C-EMDW Aeg $^{-22}$ & AM411339 & 371 & Uncultured marine bacterium clone SPOTSAPR01_5m159 & DQ009089 & 366 & 98 & Bacteroidetes \\
\hline 219-C-EMDW Aeg -23 & AM411328 & 433 & Uncultured Bacteroidetes bacterium clone JL-ETNP-Z67 & AY726974 & 426 & 98 & Bacteroidees \\
\hline 219-C-EMDW Aeg $^{-28}$ & AM411324 & 387 & Uncultured marine bacterium clone SPOTSAPR01_5m159 & DQ009089 & 384 & 99 & Bacteroidetes \\
\hline 219-EMDW Aeg -29 & AM411329 & 407 & Uncultured Bacteroidetes bacterium clone FFP21 & AY829996 & 390 & 95 & Bacteroidetes \\
\hline 219-C-EMDW Aeg -30 & AM411323 & 442 & Uncultured Bacteroidetes bacterium clone FFP74 & AY828436 & 438 & 99 & Bacteroidetes \\
\hline 219-C-EMDW Aeg $^{-39}$ & AM411330 & 339 & Uncultured bacterium clone FS266-67B-03 & DQ513081 & 333 & 98 & Bacteroidetes \\
\hline 219-C-EMDW Aeg $^{-41}$ & AM411344 & 336 & Uncultured marine bacterium clone SPOTSAPR01_5m159 & DQ009089 & 331 & 98 & Bacteroidetes \\
\hline 219-C-EMDW Aeg $^{-42}$ & AM411336 & 401 & Uncultured Flavobacteria bacterium clone SIMO-788 & AY712325 & 399 & 99 & Bacteroidetes \\
\hline 219-C-EMDW Aeg -43 & AM411337 & 375 & Uncultured marine bacterium clone Chl1.10 & DQ071031 & 359 & 95 & Bacteroidetes \\
\hline 219-C-EMDW Aeg $^{-44}$ & AM411338 & 322 & Uncultured bacterium clone FS266-38B-03 & DQ513080 & 316 & 98 & Bacteroidetes \\
\hline 219-C-EMDW Aeg $^{-45}$ & AM411333 & 473 & Uncultured bacterium clone FS266-38B-03 & DQ513080 & 465 & 98 & Bacteroidetes \\
\hline 254-C-EMDW Aeg $^{-2}$ & AM411351 & 375 & Uncultured bacterium clone FS266-38B-03 & DQ513080 & 369 & 98 & Bacteroidetes \\
\hline 254-C-EMDW Aeg $^{-3}$ & AM398934 & 437 & Uncultured green non-sulfur bacterium clone MBMPE46 & AJ567560 & 422 & 96 & Chloroflexi \\
\hline 254-C-EMDW Aeg $^{-6}$ & AM398937 & 257 & Uncultured Verrucomicrobiales Sva0821 & AJ297461 & 245 & 95 & Verrucomicrobia \\
\hline 254-C-EMDW $\mathrm{Aeg}^{-7}$ & AM411358 & 148 & Uncultured Cytophagaceae bacterium clone 1-13 & AY094494 & 143 & 96 & Bacteroidetes \\
\hline 254-C-EMDW $\mathrm{Aeg}^{-8}$ & AM398939 & 254 & Uncultured bacterium clone HF500_B6_P1 & DQ300691 & 246 & 96 & Bacteroidetes \\
\hline 254-C-EMDW Aeg $^{-9}$ & AM411352 & 418 & Uncultured bacterium clone FS266-38B-03 & DQ513080 & 417 & 99 & Bacteroidetes \\
\hline 254-C-EMDW Aeg $^{-10}$ & AM411349 & 457 & Uncultured bacterium clone FS266-38B-03 & DQ513080 & 451 & 98 & Bacteroidetes \\
\hline 254-C-EMDW Aeg $^{-12}$ & AM398935 & 359 & Unidentified eubacterium clone SAR307 & U20798 & 358 & 99 & Chloroflexi \\
\hline 254-C-EMDW Aeg -13 & AM411354 & 398 & Uncultured bacterium clone FS266-38B-03 & DQ513080 & 395 & 99 & Bacteroidetes \\
\hline 254-C-EMDW Aeg $^{-15}$ & AM398936 & 282 & Uncultured bacterium clone:Mb-NB06 & AB193900 & 260 & 92 & Bacteroidetes \\
\hline 254-C-EMDW Aeg $^{-16}$ & AM411356 & 375 & Uncultured bacterium clone FS266-38B-03 & DQ513080 & 366 & 97 & Bacteroidetes \\
\hline $254-\mathrm{C}-\mathrm{EMDW}_{\mathrm{Aeg}}-17$ & AM398938 & 244 & Uncultured bacterium clone:Mb-NB06 & AB193900 & 229 & 93 & Bacteroidetes \\
\hline 254-C-EMDW Aeg $^{-19}$ & AM411355 & 386 & Uncultured bacterium clone FS266-38B-03 & DQ513080 & 380 & 98 & Bacteroidetes \\
\hline 254-C-EMDW Aeg $^{-20}$ & AM411350 & 189 & Uncultured bacterium clone FS266-38B-03 & DQ513080 & 188 & 99 & Bacteroidetes \\
\hline 254-C-EMDW Aeg -22 & AM411357 & 360 & Flavobacteriaceae bacterium 'BSE RB 01' & AY259513 & 357 & 99 & Bacteroidetes \\
\hline $254-\mathrm{C}-\mathrm{EMDW}_{\mathrm{Aeg}}-23$ & AM411353 & 386 & Uncultured bacterium clone FS266-38B-03 & DQ513080 & 386 & 100 & Bacteroidetes \\
\hline
\end{tabular}




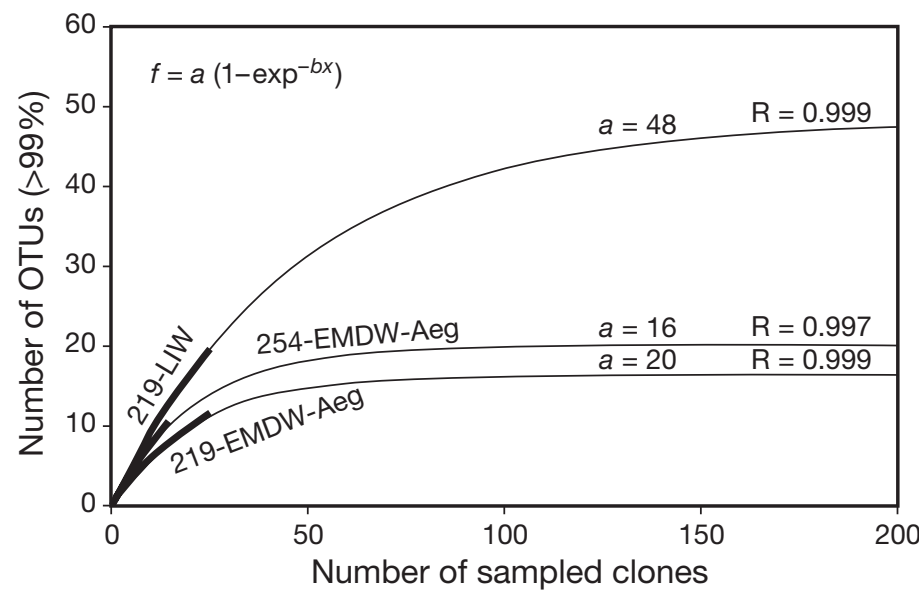

Fig. 5. Rarefaction/regression analysis based on data from 16S rDNA environmental clones; bold portion of regression lines indicates retrieved proportion of total assumed Bacteroidetes diversity. a: assumed number of OTUs; R: correlation coefficient. Rarefaction equation used was $f=$ $a\left(1-\exp ^{-b x}\right)$. Abbreviations as in Fig. 3 key

water masses by the clone libraries (219-LIW: obtained 20 , expected $48, \mathrm{R}=0.999 ; 219-\mathrm{EMDW}_{\mathrm{Aeg}}$ : obtained 12, expected 20, $\mathrm{R}=0.999 ; 254-\mathrm{EMDW}_{\mathrm{Aeg}}$ : obtained 9, expected $16, \mathrm{R}=0.997$ ).

Altogether, 3 sequence sub-clusters originating exclusively from the Mediterranean Sea and showing characteristic association with a specific water mass

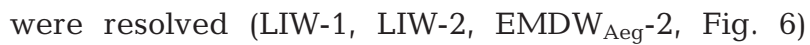
within the AGG58 cluster. In Sub-clusters LIW-1 and 2 only sequences from LIW were present. Sub-cluster $\mathrm{EMDW}_{\text {Aeg-1 }}$ contained sequences from Stn 219 (2300 m) together with some reference sequences from the Columbia River Estuary, the English Channel and the Pacific Ocean. In contrast, Sub-cluster EMDW $\mathrm{E}_{\mathrm{Aeg}}-2$ contained exclusively environmental clone sequences from $\mathrm{EMDW}_{\mathrm{Aeg}}$ of Stns 219 and 254.

\section{DISCUSSION}

In recent years, the phylum Bacteroidetes has been shown to be of major importance in the marine realm, especially for carbon conversion. Consequently, it is considered to be one of the most abundant bacterial phyla in seawater. The oligotrophic character of the Eastern Mediterranean Sea and its well known water mass distribution offer possibly unique conditions for bacteria of this phylum, and analysis of the Bacteroidetes community in these waters is therefore of special interest. A molecular approach, providing detailed information on the microbial community structure, was performed in the present study in order to assess diversity and distribution of Bacteroidetes. Studies using FISH for the detection of
Bacteroidetes have demonstrated high abundances of this bacterial group in various marine environments (Glöckner et al. 1999, Abell \& Bowman 2005a). Several studies further emphasized the under-representation of this bacterial lineage in PCR-based studies when general 16S rRNA gene-targeted eubacterial primers are used (Bowman et al. 1997, Pinhassi et al. 1997, Glöckner et al. 1999, Cottrell \& Kirchman 2000, Eilers et al. 2000). After comparison of Bacteroidetes type strain sequences from GenBank, the newly designed primer Cyt-1020R was successfully applied as antisense primer for amplification of Bacteroidetes sequences from environmental samples. As shown by sequencing of DGGE bands and environmental clones, Cyt-1020R appears to be especially suitable for amplifying representatives of the yet uncultured AGG58 cluster within the new family Cryomorphaceae (Bowman et al. 2003). While this study was in progress, other oligonucleotides targeting the Bacteroidetes phylum have been described. In contrast to the present study, these specific sense primers were combined with general eubacterial antisense primers (O'Sullivan et al. 2002, Kirchman et al. 2003). All primer sets amplified a DNA fragment comprising approx. 1000 nt. Thus, both approaches, i.e. the combination of a general sense primer with a specific antisense primer (as in this study), and the combination of a specific sense primer with a general antisense primer as in the studies of O'Sullivan et al. (2002) and Kirchman et al. (2003) appear to be useful for specifically amplifying Bacteroidetes sequences from environmental samples.

Using the Bacteroidetes-specific primer combination 27F/Cyt-1020R, we obtained molecular evidence for AGG58 cluster representatives even in the oligotrophic Eastern Mediterranean Sea. Our data confirmed the results of O'Sullivan et al. (2004), who stated that the AGG58 cluster is ubiquitous.

DGGE analyses resulted in the detection of several characteristic bands for distinct water masses, and cluster analysis/ANOSIM of DGGE gels confirmed the observed depth-specific distribution of Bacteroidetes sequences. At Stn 295 in the Ionian Basin especially, samples from different water masses clearly fell into separate clusters. In contrast to Stns 219 in the Levantine Basin and Stn 254 in the Cretan Passage, Stn 295 is the only location unaffected by the EMT (B. Manca pers. comm.). Thus, in regard to water mass distribution, Stn 295 can be considered comparably stable. In contrast, at Stn 254 in the Cretan Passage, the $500 \mathrm{~m}$ sample (LIW) falls within the EMDW $_{\text {Aeg }}$ cluster, possibly due to substantial mixing processes caused by the EMT. The deep waters at this station were especially subject to substantial changes, and perhaps a stable Bacteroidetes community was not yet established in 
Fig. 6. Maximum likelihood 16S rDNA phylogenetic tree (PHYML, evolutionary model: GTR) based on 51 partial sequences (approx. $400 \mathrm{nt}$ ) of environmental clones from 'Mediterranean' cluster and their closest relatives. Numbers on nodes indicate bootstrap values (100 replicates). Vertical lines mark water mass specific sub-clusters. LIW-1 and -2: sequences from 219-LIW; EMDW-Aeg-1: sequences from 219-EMDW $W_{\text {Aeg }}$ and reference sequences; EMDW-Aeg-2: sequences from 219-EMDW ${ }_{\text {Aeg }}$ and 254-EMDW ${ }_{\mathrm{Aeg}}$. IS: Isolation source; other abbreviations as in Fig. 3 key

this water mass. In general, the DGGE gel cluster analysis clearly showed depth-specific distribution of certain Bacteroidetes representatives at all stations. However, depth-specific distribution of all Bacteroidetes representatives seems unlikely. Certain DGGE bands appeared throughout the depth profile, thus providing another possible explanation for the 'wrong' affiliation achieved by cluster analysis (Stn 219$10 \mathrm{~m}$ affiliated with $\mathrm{EMDW}_{\text {Aeg }}, 254$ to $500 \mathrm{~m}$ affiliated with $\mathrm{EMDW}_{\text {Aeg }}$ ).

A BLAST search revealed similarity values ranging from 87 to $100 \%$ for DGGE band sequences, with most sharing 95 to $98 \%$ similarity with their closest relatives. Assignment of 16S rDNA sequences of excised bands (approx. $190 \mathrm{nt})$ to the large database supplied by the ARB project permitted affiliation with different bacterial groups.

The majority of excised band sequences formed a separate lineage within the AGG58 cluster, indicating a specific Bacteroidetes community. Sequences from clone libraries confirmed the data obtained by DGGE band sequencing. Environmental clone sequences and DGGE band sequences were assigned to a separate branch within the AGG58 cluster, indicating that both separation techniques resolved a comparable range of sequence variation in the samples. The total diversity of Bacteroidetes can be assumed to be even higher than revealed by our experiments as shown by the results of rarefaction/regression analysis.

Similarity values for environmental clones ranged from 91 to $100 \%$, with most environmental clones showing similarities of 96 to $98 \%$ to their closest relatives. With regard to the Bacteroidetes phylum, the similarity values were exceptionally high, but
Tenacibaculum maritimum $\mathrm{M} 64629$

Owenweeksia honkongensis AB125062

219-C-LIW-40

-219-C-EMDW-Aeg-1

219-C-LIW-40g 219-C-LIW-41 100 $\begin{array}{ll}219-C-L I W-38 \\ 219-C-L I W-30 \\ 219-C-L I W-37 \\ 219-C-L I W-25\end{array}$

Uncultured marine bacterium AY923013, IS: Sargasso Sea

Uncultured marine bacterium DQ071031, IS: Gulf Stream Ring
$219-C-$ LIW-59
$219-$ C-LIW-32
Uncultured Bacteroidetes bacterium AY829996, IS: Loch Fyne
$219-$ C-EMDW-Aeg-13
$219-$ C-EMDW-Aeg-29
$219-C-$ LIW 46
$219-C-L I W-54$

$\mathrm{L}_{219-C-L I W}^{219}-54$
$219-C-$ EMDW-Aeg-43

Uncultured Flavobacteria bacterium AY712325
$219-C-E M D W-A e g-12$
$219-C-E M D W-A e g-42$
$219-C-E M D W-2$
Uncultured Cytophagales bacterium AF141488, IS: Columbia River Estuary
Uncultured Bacteroidetes AY254714, IS: English Channel

ultured marine bacterium DQ009089, IS: Pacific Ocean off San Pedro

219-C-EMDW-Aeg-41 |

219-C-EMDW-Aeg-21

63 219-C-EMW-Aeg-44

219-C-EMW-A

219-C-EMDW-Aeg-7

219-C-EMDW-Aeg-28

219-C-EMDW-Aeg-19

219-C-EMDW-Aeg-11

219-C-EMDW-Aeg-6

$219-C-L I W-26$
$219-C-L I W-43$
21W

219-C-LIW-45

219-C-LIW-44

-219-C-LIW-49

219-C-LIW-29

219-C-LIW-57

254-C-EMDW-Aeg-20

Uncultured bacterium DQ513080, IS: ridge flank crustal fluids

254-C-EMDW-Aeg-10

254-C-EMDW-Aeg-9

254-C-EMDW-Aeg-13

254-C-EMDW-Aeg-23

219-C-LIW-23

219-C-EMDW-Aeg-10

254-C-EMDW-Aeg-19

254-C-EMDW-Aeg-2

254-C-EMDW-Aeg-16

219-C-EMDW-Aeg-15

219-C-EMDW-Aeg-20

219-C-EMDW-Aeg-45

219-C-EMDW-Aeg-14

219-C-EMDW-Aeg-3

219-C-EMDW-Aeg-44

\section{EMDW-Aeg-2}

since the database is being constantly enlarged due to growing interest in this bacterial phylum, especially in the marine realm, such high values are to be expected.

The environmental clone sequences from the Eastern Mediterranean Sea were closely related to AGG58 Branch 2 clones from the study by O'Sullivan et al. (2004). Thus, AGG58 Branch 2 together with sequences from the Mediterranean Sea and sequences obtained from other marine or marine-related locations (e.g the Sargasso Sea, Arctic sea ice) may reflect Bacteroidetes representatives specialized or adapted to extremely oligotrophic marine waters. O'Sullivan et al. (2004) reported a ubiquitous distribution of 
the AGG58 cluster but hypothesized that different members of the cluster were specialized for different ecological conditions, supporting this assumption.

The sequences from environmental clones also confirmed the hypothesis of a depth-specific distribution of certain Bacteroidetes representatives within the Eastern Mediterranean Sea. Environmental clone sequence Sub-clusters LIW-1 and -2 were specific for intermediate water layers (Stn 219), and Sub-cluster $\mathrm{EMDW}_{\mathrm{Aeg}}$-2 (Stn 219: Clones 3, 14, 20, 44, 45; Stn 254: Clones 2, 10, 16, 19) for deep waters (Fig. 6). To date, depth-specific distribution has been reported for several bacterial groups (e.g. green non-sulfur bacteria, SAR 11 cluster and Deltaproteobacteria), but to our knowledge, this study presents the first molecular evidence for depth-specific distribution of Bacteroidetes representatives.

Two major properties of the water column may be responsible for the observed depth-specific distribution: depth itself (increasing hydrostatic pressure) and the water mass boundaries, primarily defined through physical variations. The specific effects of the water mass properties and depth (hydrostatic pressure) upon bacterial community structure cannot be easily distinguished.

Although hydrostatic pressure is considered to be of relevance for the spatial distribution of bacteria within the water column (Lee \& Fuhrman 1991, Gordon \& Giovannoni 1996, Acinas et al. 1997, 1999, Field et al. 1997, Wright et al. 1997, Pinhassi et al. 2000), it can be assumed to have but minor influence on the bacterial community composition in surface and intermediate waters. Specific adaptation to high hydrostatic pressure may explain the high similarity of Bacteroidetes communities in deep waters but seems unlikely for intermediate waters.

Different characteristics of water masses may contribute to the different Bacteroidetes communities at different depths. Besides differences in temperature and salinity, one outstanding characteristic is the content of organic matter (DOC and POC). Seritti et al. (2003) found a direct correlation between DOC concentration and salinity in different water masses of the Ionian Sea. They observed higher DOC values

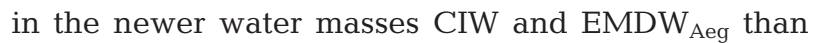

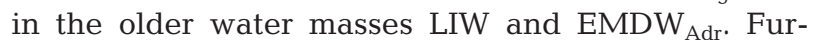
thermore, DOC values were correlated with microbial activities, as measured by oxygen consumption (Seritti et al. 2003). The major contribution of Bacteroidetes representatives to nutrient and carbon recycling (Suzuki et al. 2001, Kirchman et al. 2003) and different DOC concentrations in different water masses (Seritti et al. 2003) can be explained by the water-mass-specific distribution of Bacteroidetes sequences found in this study. In the Eastern
Mediterranean Sea, production is mainly due to recycling of nutrients (Kress et al. 2003). Because of their special physiological capabilities, members of the Bacteroidetes would have an important function in these waters, despite the highly oligotrophic nature of the region. In the Eastern Mediterranean Sea, regenerated production mainly relies on microbial turnover (primary production limited by phosphorus; Krom et al. 1991, Malanotte-Rizzoli et al. 2003). In spring and early summer, degradation of organic material produced during the spring phytoplankton bloom may cause high abundances of Bacteroidetes in intermediate and deep water masses. Differing preferences with respect to the amount and composition of organic matter may be the reason for depthspecific distribution of these bacteria. The amount and quality of organic matter can be assumed to change with depth due to the ongoing degradation and conversion in upper layers. Because the amount of organic matter (at least in regard to DOC; Seritti et al. 2003) has also been observed to differ between water masses, different Bacteroidetes representatives (as possible producers of DOC) may develop in different water mass bodies.

Zaballos et al. (2006) proposed the presence of a unique prokaryotic community within the Mediterranean Sea, and data obtained during the present study for the Bacteroidetes confirmed this. Bacteroidetes sequences from DGGE bands as well as from environmental clones were positioned within the ubiquitous AGG58 cluster, but formed a coherent lineage within the cluster together with but a few reference sequences from other habitats (Fig. 4).

Although many bacterial taxa are known to be globally distributed, a specific distribution along physicochemical gradients (e.g. water mass boundaries) were demonstrated for the Bacteroidetes phylum in the present study. Thus, the aerobic water column within the ocean may represent a heterogeneous habitat, specifically inhabited by different bacterial taxa.

Acknowledgements. For financial support, the authors thank the Deutsche Forschungsgemeinschaft (Meteor Cruise 44/4, DFG, IM 12/9-1). The authors are grateful to the captain and crew of RV 'Meteor' for support during the cruise. We also thank Dr. Birgit Klein (Institut für Umweltphysik, University of Bremen, Germany) and Dr. Bruno Manca (Istituto Nazionale di Oceanografia e di Geofisica Sperimentale, Trieste, Italy) for detailed information about water mass properties as well as Dr. Nurit Kress (National Institute of Oceanography, Israel Oceanographic Limnological Research Haifa, Israel) for details of nutrient conditions. We thank coworkers of our group at IFM-GEOMAR (Kiel): Dr. Gudrun Karsten for uncomplaining help with phylogenetic analyses, Dr. Ralf Petri (Max-Planck-Institut für Züchtungsforschung, Köln) for primer design, Regine Koppe for prokaryotic counts and Frank Lappe for technical assistance. 


\section{LITERATURE CITED}

Abell GCJ, Bowman JP (2005a) Ecological and biogeographic relationships of class Flavobacteria in the Southern Ocean FEMS Microbiol Ecol 51:265-277

Abell GCJ, Bowman JP (2005b) Colonization and community dynamics of class Flavobacteria on diatom detritus in experimental mesocosms based on Southern Ocean seawater. FEMS Microbiol Ecol 53:379-391

Abrams ES, Stanton VP (1992) Use of denaturing gradient gel electrophoresis to study conformational transitions in nucleic acids. Methods Enzymol 212:71-104

Acinas SG, Rodriguez-Valera F, Pedros-Alio C (1997) Spatial and temporal variation in marine bacterioplankton diversity as shown by RFLP fingerprinting of PCR amplified $16 \mathrm{~S}$ rDNA. FEMS Microbiol Ecol 24:27-40

Acinas SG, Anton J, Rodriguez-Valera F (1999) Diversity of free-living and attached bacteria in offshore western Mediterranean waters as depicted by analysis of genes encoding 16S rRNA. Appl Environ Microbiol 65:514-522

Altschul SF, Madden TL, Schäffer AA, Zhang J, Zhang Z, Miller W, Lipman DJ (1997) Gapped BLAST and PSIBLAST: a new generation of protein database search programs. Nucleic Acids Res 25:3389-3402

Bano N, Hollibaugh JT (2002) Phylogenetic composition of bacterioplankton assemblages from the Arctic Ocean. Appl Environ Microbiol 68:505-518

Bowman JP, McCammon SA, Brown MV, Nichols DS, McMeekin TA (1997) Diversity and association of psychrophilic bacteria in Antarctic sea ice. Appl Environ Microbiol 63:3068-3078

Bowman JP, Nichols CM, Gibson JAE (2003) Algoriphagus ratkowskyi gen. nov., sp. nov., Brumimicrobium glaciale gen. nov., sp. nov., Cryomorpha ignava gen. nov., sp. nov. and Crocinitomix catalasitica gen. nov., sp. nov., novel flavobacteria isoloated from various polar habitats. Int $\mathrm{J}$ Syst Evol Microbiol 53:1343-1355

Brosius JM, Poindexter ML, Kennedy J, Noller HF (1978) Complete nucleotide sequence of a 16S ribosomal RNA gene from Escherichia coli. Proc Natl Acad Sci USA 75: 4801-4805

CIESM (Commission Internationale pour l'Exploration Scientifique de la Mer Mediterranée) (2003) Mare incognitum? Exploring Mediterranean deep-sea biology? CIESM Workshop Monogr Comm Int Explor Sci Mer Mediterr 23:128 (also available at: www.ciesm.org/publications/Herraklion 03.pdf)

Cottrell MT, Kirchman DL (2000) Natural assemblages of marine proteobacteria and members of the CytophagaFlavobacter cluster consuming low- and high-molecularweight dissolved organic matter. Appl Environ Microbiol 66:1692-1697

Crump BC, Armbrust EV, Baross JA (1999) Phylogenetic analysis of particle-attached and free-living bacterial communities in the Columbia river, its estuary, and the adjacent coastal ocean. Appl Environ Microbiol 65:3192-3204

DeLong EF, Franks DG, Alldredge AL (1993) Phylogenetic diversity of aggregate-attached vs free-living marine bacterial assemblages. Limnol Oceanogr 38:924-934

Eilers H, Pernthaler J, Glöckner FO, Amann R (2000) Culturability and in situ abundance of pelagic bacteria from the North Sea. Appl Environ Microbiol 66:3044-3051

Field KG, Gordon D, Wright T, Rappé M, Urbach E, Vergin K, Giovannoni SJ (1997) Diversity and depth-specific distribution of SAR11 cluster rRNA genes from marine planktonic bacteria. Appl Environ Microbiol 63:63-70

Fry JC (2000) Diversity of bacteria in marine environments.
Workshop Monogr Comm Int Explor Sci Mer Mediterr Ser 11:29-31

Glöckner FO, Fuchs BM, Amann R (1999) Bacterioplankton compositions of lakes and oceans: a first comparison based on fluorescence in situ hybridization. Appl Environ Microbiol 65:3721-3726

Gordon DA, Giovannoni SJ (1996) Detection of stratified microbial populations related to Chlorobium and Fibrobacter species in the Atlantic and Pacific Oceans. Appl Environ Microbiol 62:1171-1177

Guindon S, Gascuel O (2003) A simple, fast, and accurate algorithm to estimate large phylogenies by maximum likelihood. Syst Biol 52:696-704

Hagström $\AA$ (2000) Marine bacterioplankton diversity and activity. Workshop Monogr Comm Int Explor Sci Mer Mediterr Ser 11:35-36

Hagström Å, Pinhassi J, Zweifel UL (2000) Biogeographical diversity among marine bacterioplankton. Aquat Microb Ecol 21:231-244

Jürgens K, Pernthaler J, Schalla S, Amann R (1999) Morphological and compositional changes in a planktonic bacterial community in response to enhanced protozoan grazing. Appl Environ Microbiol 65:1241-1250

Kirchman DL (2002) The ecology of Cytophaga-Flavobacteria in aquatic environments. FEMS Microbiol Ecol 39:91-100

Kirchman DL, Yu LY, Cottrell MT (2003) Diversity and abundance of uncultured Cytophaga-like bacteria in the Delaware Estuary. Appl Environ Microbiol 69:6587-6596

Kress N, Manca BB, Klein B, Deponte D (2003) Continuing influence of the changed thermohaline circulation in the Eastern Mediterranean on the distribution of dissolved oxygen and nutrients: physical and chemical characterization of the water masses. J Geophys Res C 108:8109, doi:10.1029/2002JC001397

Krom MD, Kress N, Brenner S, Gordon LI (1991) Phosphorus limitation of primary productivity in the Eastern Mediterranean Sea. Limnol Oceanogr 36:424-432

Lascaratos A, Roether W, Nittis K, Klein B (1999) Recent changes in deep water formation and spreading in the eastern Mediterranean Sea: a review. Prog Oceanogr 44: $5-36$

Lee SH, Fuhrman JA (1991) Spatial and temporal variation of natural bacterioplankton assemblages studied by total genomic DNA cross-hybridization. Limnol Oceanogr 36:1277-1287

Ludwig W, Strunk O, Westram R, Richter L and 27 others (2004) ARB: a software environment for sequence data. Nucleic Acids Res 32:1363-1371

Malanotte-Rizzoli P, Manca BB, Marullo S, d'Alacala MR and 21 others (2003) The Levantine Intermediate Water Experiment (LIWEX) Group: Levantine basin-a laboratory for multiple water mass formation processes. J Geophys Res C 108:8101, doi:10.1029/2002JC001643

Manca BB, Budillon G, Scarazzato P, Ursella L (2003) Evolution of dynamics in the Eastern Mediterranean affecting water mass structures and properties in the Ionian and Adriatic Seas. J Geophys Res C 108:8102, doi:10.1029/ 2002JC001664

Marchesi JR, Sato T, Weightman AJ, Martin TA, Fry JC, Hiom SJ, Wade WG (1998) Design and evaluation of useful bacterium-specific PCR primers that amplify genes coding for bacterial 16S rRNA. Appl Environ Microbiol 64:795-799

Muyzer G, Dewaal EC, Uitterlinden AG (1993) Profiling of complex microbial populations by denaturing gradient gel electrophoresis analysis of polymerase chain reactionamplified genes-coding for 16S ribosomal RNA. Appl Environ Microbiol 59:695-700 
O'Sullivan LA, Weightman AJ, Fry JC (2002) New degenerate Cytophaga-Flexibacter-Bacteroides-specific $16 \mathrm{~S}$ ribosomal DNA-targeted oligonucleotide probes reveal high bacterial diversity in River Taff epilithon. Appl Environ Microbiol 68:201-210

O'Sullivan LA, Fuller KE, Thomas EM, Turley CM, Fry JC, Weightman AJ (2004) Distribution and culturability of the uncultivated 'AGG58 cluster' of the Bacteroidetes phylum in aquatic environments. FEMS Microbiol Ecol 47: 359-370

Petri R, Imhoff JF (2001) Genetic analysis of sea-ice bacterial communities of the Western Baltic Sea using an improved double gradient method. Polar Biol 24:252-257

Pinhassi J, Zweifel UL, Hagström ^̊ (1997) Dominant marine bacterioplankton species found among colony-forming bacteria. Appl Environ Microbiol 63:3359-3366

Pinhassi J, Winding A, Binnerup S, Hagström Å (2000) Spatial distribution of marine bacterioplankton species. CIESM Workshop Monogr Comm Int Explor Sci Mer Mediterr Ser 11:49-50

Pinhassi J, Sala MM, Havskum H, Peters F, Guadayol O, Malits A, Marrasé C (2004) Changes in bacterioplankton composition under different phytoplankton regimens. Appl Environ Microbiol 70:6753-6766

Rappé MS, Kemp PF, Giovannoni SJ (1997) Phylogenetic diversity of marine coastal picoplankton 16S rRNA genes cloned from the continental shelf off Cape Hatteras, North Carolina. Limnol Oceanogr 42:811-826

Reichenbach H (1991) The Cytophagales. In: Balows A, Trüper HG, Dworkin M, Harder W, Schleifer KH (eds) The prokaryotes. Springer-Verlag, Berlin, p 3631-3675

Roether W, Manca BB, Klein B, Bregant D, Georgopoulos D, Beitzel V, Kovacevic V, Luchetta A (1996) Recent changes in Eastern Mediterranean deep waters. Science 271: 333-335

Schlitzer R, Roether W, Oster H, Junghans HG, Hausmann M, Johannsen H, Michelato A (1991) Chlorofluoromethane and oxygen in the Eastern Mediterranean. Deep-Sea Res A 38:1531-1551

Seritti A, Manca BB, Santinelli C, Murru E, Boldrin A, Nannicini L (2003) Relationships between dissolved organic carbon (DOC) and water mass structures in the Ionian Sea (winter 1999). J Geophys Res C 108:8112, doi:10.1029/ 2002JC001345

Suzuki MT, Rappé M, Haimberger ZW, Winfield H, Adair N, Ströbel J, Giovannoni SJ (1997) Bacterial diversity among small subunit rRNA gene clones and cellular isolates from

Editorial responsibility: Gerhard Herndl, Den Burg, Texel, The Netherlands the same seawater sample. Appl Environ Microbiol 63: 983-989

Suzuki MT, Nakagawa Y, Harayama S, Yamamoto S (2001) Phylogenetic analysis and taxonomic study of marine Cytophaga-like bacteria: proposal for Tenacibaculum gen. nov with Tenacibaculum maritimum comb. nov and Tenacibaculum ovolyticum comb. nov., and description of Tenacibaculum mesophilum sp. nov and Tenacibaculum amylolyticum sp. nov. Int J Syst Evol Microbiol 51: 1639-1652

Theocharis A, Georgopoulos D, Lascaratos A, Nittis K (1993) Water masses and circulation in the central region of the Eastern Mediterranean-Eastern Ionian, South Aegean and Northwest Levantine, 1986-1987. Deep-Sea Res II 40: 1121-1142

Theocharis A, Balopoulos E, Kioroglou S, Kontoyiannis H, Iona A (1999) A synthesis of the circulation and hydrography of the South Aegean Sea and the Straits of the Cretan Arc (March 1994-January 1995). Prog Oceanogr 44:469-509

Thompson JD, Higgins DG, Gibson TJ (1994) Clustal-Wimproving the sensitivity of progressive multiple sequence alignment through sequence weighting, position-specific gap penalties and weight matrix choice. Nucleic Acids Res 22:4673-4680

Uphoff HU, Felske A, Fehr W, Wagner-Dobler I (2001) The microbial diversity in picoplankton enrichment cultures: a molecular screening of marine isolates. FEMS Microbiol Ecol 35:249-258

Wright TD, Vergin KL, Boyd PW, Giovannoni SJ (1997) A novel delta-subdivision proteobacterial lineage from the lower ocean surface layer. Appl Environ Microbiol 63: 1441-1448

Yanisch-Peron C, Viera J, Mesing J (1985) Improved M13 phage cloning vectors and host strains: nucleotide sequences of the M13 mp18 and pUC19 vectors. Gene 33: $103-119$

Younis M (2001) Studies on the diversity of purple sulfur bacteria in the Baltic Sea, Lake Nasser (Egypt) and the Red Sea based on classical and molecular genetic approaches. $\mathrm{PhD}$ thesis, Faculty of Mathematical and Natural Sciences, Christian-Albrechts-University of Kiel

Zaballos M, Lopez-Lopez A, Ovreas L, Bartual SG and 6 others (2006) Comparison of prokaryotic diversity at offshore oceanic locations reveals a different microbiota in the Mediterranean Sea. FEMS Microbiol Ecol 56:389-405

Submitted: April 19, 2006; Accepted: December 14, 2006 Proofs received from author(s): March 7, 2007 